Document downloaded from:

http://hdl.handle.net/10251/157210

This paper must be cited as:

Saz Rubio, MMD. (2019). The pragmatic-semiotic construction of male identities in contemporary advertising of male grooming products. Discourse \& Communication. 13(2):192-227. https://doi.org/10.1177/1750481318817621

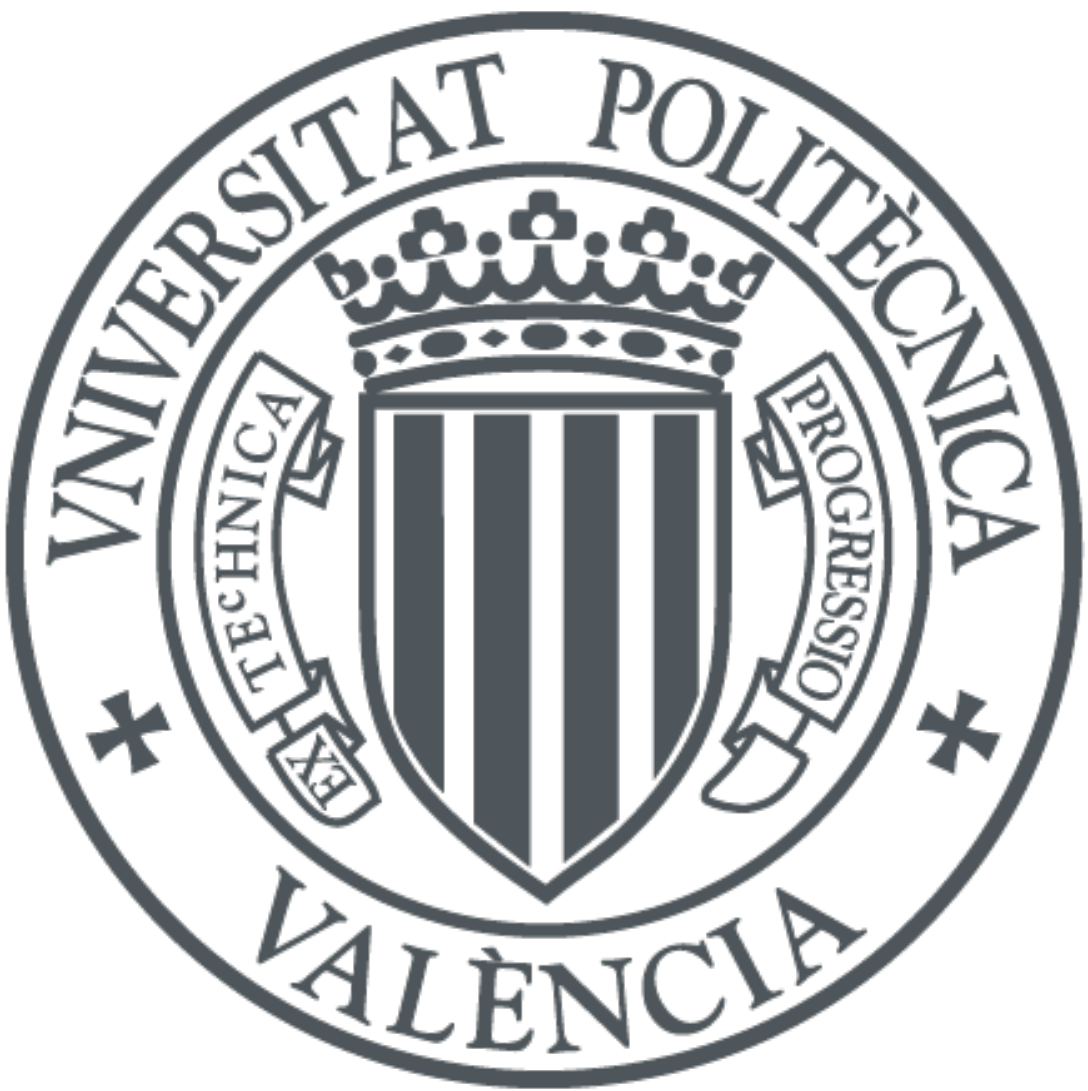

The final publication is available at

https://doi.org/10.1177/1750481318817621

Copyright SAGE Publications

Additional Information 


\title{
The pragmatic-semiotic construction of male identities in contemporary advertising of male grooming products
}

\begin{abstract}
This article aims to unveil how male identities are constructed in a corpus of male toiletries TV ads through a pragmatic and multimodal analysis of a set of implicit assumptions conveyed about the male participants in the ads. The validity of these assumptions is first empirically tested with a group of ten male informants and then those implied meanings are bundled into thematic cores for their qualitative and quantitative description. Findings reveal that these ads still rely on stereotypical constructs and traditional discourses of what it takes to be a man. For example, men are invited to consume grooming products but reminded to do it the men's way. Men are also reminded of their sexual power to seduce and attract women with the aid of the product. Likewise, by portraying male ad personae in traditional manly activities while emphasizing their toughness and body strength, or their resourcefulness when faced with challenging situations, the ads portrayed a rather skewed view of contemporary men which fails to take into account the myriad of roles a modern man can play in contemporary societies.
\end{abstract}

\section{Introduction}

Nowadays, we live in a society in which gender rules are in a constant state of change and where gender roles, once strictly and traditionally defined, have changed, widened and become fuzzier. For example, men, who used to define their masculinity in terms of their roles as 'heroes' or 'breadwinners' (Kimmel, 2012), are now caught between the need to fulfil pervasive simultaneous roles which may not only urge them to act as the providers, but also to have an active parenting role with regard to childcare tasks, to take up more responsibilities, and to share the workload of household chores. In other words, the traditional values embodied within the concept of hegemonic masculinity formulated in the 80s, and which helped define what a man was, do not seem to hold as much cultural currency as they used to do (Connell, 1995; Connell and Messerschmidt, 2005). This is understandable if we take into account that research in the field of men's studies has acknowledged the fact that there is not just one way to 'be a man', as different male styles and masculinities tend to coexist and change over time and space throughout different historical and cultural contexts (Carrigan et al, ; Morgan 1992) ${ }^{1}$.

Another change in male roles, albeit of a different nature, concerns men's increasing participation in consuming practices since the 80s. In fact, men, as well as women, are nowadays regarded as active commodity purchasers (Kacen, 2000), and hence, the activity of consumption has become an acceptable male activity and a conventional source through which to seek self-definition and fulfilment (cf. Kacen, 2000; Gill et al. 2005; McNeill and Douglas, 2011; McNeill and Firman, 2014). In this vein, men's current consumption practices are no longer restricted to 'cars, alcohol, certain brands of cigarettes, mechanical tools, business products and life insurance (Craig, 1992; Fowles, 1996; Wernick, 1991), as products traditionally associated with the male market. As pointed out by Hall et al. (2012:209): “Modern men, it seems, are fascinated

\footnotetext{
${ }^{1}$ Even if we acknowledge the existence of multiple masculinities, it is also true that some forms of masculinity have always been viewed as more hegemonic and, hence, characterised by men's dominance over women but also by the existence of a hierarchy among men (Carrigan et al., 1985).
} 
with their appearance, investing time and money in their personal appearance, through diet and lifestyle choices, fitness regimes, and the purchase of consumer goods, including clothing, accessories, and cosmetics”. In fact, men have increased their consumption of grooming products or toiletries and this has brought a new relationship for male consumers with these commodities. Proof of that is the fact that men's consumption of grooming products has dramatically risen in the last two decades. In fact, the global male grooming market, which was valued at $\$ 47.2$ billion in 2015 , is projected to reach $\$ 60.7$ billion by 2020, according to Euromonitor. For example, men's toiletries (men's bath and shower, deodorant and skin and hair care) comprised 37\% of total USA sales in 2015 and were valued at $\$ 17.5$ billion with a growth expectation that will make it reach $\$ 23.9$ billion by $2020^{2}$. These staggering figures have also found their counterpart in the British market with sales of male cosmetics and toiletries going up 37.3\% between the years 1998 and 2003 (Hakala, 2003:57) and with an approximate of one million pounds by 2016 (L’Oréal 2010; Mintel, 2012).

Some of the factors responsible for this growth in the consumption of male grooming products in the 90s and in the interest for fashion trends could be the changing roles of men and women in society caused by economic, social, historical and political changes (cf. Pleck, 1981): for example, a greater proportion of women in gainful employment, a shift to an economy based on service rather than industrialization, and the advancement of feminist principles which have challenged the traditional patriarchal ideals (Gill, 2003). These changes, which could have been motivated by three waves of feminism and the empowerment of women, have been thought to pose a threat to men's identity and to have led to a destabilization of American masculinity (cf. Pascoe, 2003). Thus, men's forays into traditional feminine territory would be best explained as motivated by men's need to reaffirm their status as real men through consumption, or what has been termed as the "compensatory consumption thesis" (Holt and Thompson, 2004:425). In addition, during the postmodern era (middle 80s), a person also got to be valued on the basis of their physical appearance and what s/he consumed (cf. Firat \& Venkatesh 1993, 235, Hakala, 2003) and as a result, appearance became a key feature of western consumer societies and a crucial resource for the construction of multiple identities (cf. Giddens, 1991; Featherstone, 1991).

Within this context, men have started to become more concerned about their appearance (Ostberg, 2009; Ross, 2012; Salzman et al., 2005) and to pay more attention to how they look in terms of health and well-being (cf. Nixon, 2000; Patterson and Elliot, 2002; Ridder, 2005; Thompson and Hirschman, 1995). This has led, according to Patterson and Elliott (2002), to the rise of a "new hegemonic masculinity", in which there has been a trend towards the feminization of manly activities.

As a result, global companies traditionally devoted to the female market, such as Nivea or L'Oréal, started marketing products for men in an attempt to possibly address these societal changes and take such new customers on board, even if that means effectively blurring gender lines in their attempt. Accordingly, they have switched focus from the traditional shaving razors and foams to niche products, such as facial and antiwrinkle creams, toning products, and even mascara (cf. Harrison, 2008). The result has been not only greater product availability for men and an increased awareness of such grooming choices, but also the appearance of new male identities closely related to current consumption patterns (cf. Barthel, 1988; Gill et al., 2005; Schroeder and Zwick, 2004). Thus, men who are engaged in non-conventional masculine activities can claim to be metrosexuals (Simpson, 1994, 2002), übersexuals (Salzman et al., 2005), 'new men'

2 "Deep dive: global male grooming market", Fund Global Retail and Tech (https://www.fungglobalretailtech.com/research/deep-dive-global-male-grooming-market/). 
(Benwell, 2003; Wicks and Mills, 2000), or 'new lads' (Benwell, 2003), 'child-men' or simply 'guys' (Bynon, 2002), labels all motivated by media representations of men. 'The new man' emerged in the 1980s as a reaction to feminist ideas and to a higher visibility of women in the workforce, and referred to a narcissist man worried about his own physical appearance and more in touch with his feminine side (Mort, 1996; Nixon, 1996). In the 1990s, 'the new man' was criticized for being unrealistic and a new representation of masculinity was born in men's magazines, i.e., the less feminine 'new lad', who rejected the values embraced by his predecessor. However, the new millennium brought a new male type, that of the 'metrosexual' (Simpson, 2002), to refer to a man 'less certain of his identity and much more interested in his image..." (Simpson, 2002:1). As happened with the other types, the hard male type of the 'übersexual' came to replace the softer one of the 'metrosexual', and to define a new generation of men who are "supremely confident, (without being obnoxious), masculine, stylish and committed to uncompromising quality in areas of life (Salzman, et al., 2005:76)”.

The role that the mass media have played in helping reflect such changes, and in making the male body more visible than it was in the middle $80 \mathrm{~s}$, seems, thus, indisputable (cf. Hall et al., 2018). Not only TV series and movies have incorporated male participants who consume grooming products, but also research about male depictions in men's style magazines has been prolific (cf. Alexander, 2003; Byrnes, 2006; Kosetzi \& Polyzou, 2009; or Meuser, 2001, to name a few).

With regard to the field of advertising, extensive literature has traditionally focused on the representation of the genders and their roles with a special focus on the representation of women ${ }^{3}$. This interest in female media representations in ads was, in part, initially fuelled by second wave feminism, a period in which scholarly work paid more attention to how women were represented, the type of products they advertised and the occupations they held, always in comparison with their male counterparts. For its part, the lack of interest in male depictions and masculinity during this period, indirectly helped convey the idea that male portrayals were not necessary as there was nothing to be questioned due to their being a fixed concept. In fact, one of the possible reasons for the invisibility of male representations may have been the prevailing power of hegemonic masculinity (Connell, 1995). In other words, as Kimmel (2004) stated, the hegemonic male was thought to be strong, capable and successful and authoritative or rather "a man in power, a man with power, and a man of power" (Kimmel, 2004: 184). However, even if masculinity was once considered as something normal, fixed or too natural to be explained (cf. MacKinnon 2003, p. 21), what the advent of postmodernism brought into question was, in fact, the fixedness and rigidity of the concept. As a result, more and more scholars began paying attention to the representation of men's roles and masculinities in the field of advertising in general, to such extent that there is nowadays a plethora of research on this topic (cf. Bogetić, 2018; Brandth, 1995; Daechun, 2007; Jackson, 1994; 1993; Luyt, 2012; Milani, 2018; Patterson and Elliott, 2002; Schroeder and Zwick, 2004, among others).

However, the way male identities are enacted in the traditional arena of grooming products has received scant attention over the last twenty years despite the fact that men are active consumers of such products. Exceptions are the content analyses carried out by Kervin, (1990), Kolbe \& Albanese (1996), Alexander (2003), Attwood (2005), or Hakala's (2003, 2006), de Gregorio-Godeo’s (2009), Harrison's (2008) and Scheibling's (2014) studies on male representations in print advertisements for grooming products

\footnotetext{
${ }^{3}$ Rudy et al. (2010a, 2010b) include a thorough description of the most updated quantitative content analyses of gender roles in a wide variety of media, including TV advertising.
} 
from different men's style magazines together with Feasy's qualitative research (2009) on the representation of men in the Lynx TV ads.

Against this backdrop, and considering that masculinities are many and multiple, this paper aims to fill such a research gap by analysing a corpus of contemporary TV ads featuring male grooming products to assess the most predominant themes around which male identities are discursively and visually constructed. In other words, it is well worth examining how masculinity and male representations are enacted in the field of advertising, as Feasy (2009: 358) states:

\footnotetext{
It is important that we do not simply ignore, overlook or discount those representations of the male that have dominated and continue to dominate small-screen commercials. Rather, it is crucial that we examine those concentrated images of masculinity, manhood and the male role that are being depicted in these everyday (and too often, overlooked) short media texts.
}

In order to achieve this objective, my main aim is to carry out a pragmatic and multimodal analysis of the implied meanings conveyed, more or less forcefully, about the male persona in the ads studied, and, to a lesser extent, about the products advertised. As the recovery of implicatures could be said to be highly perceiver-dependent, I have employed statistical tools that calculate inter-examiner agreement to back up results from a first qualitative analysis carried out by the researcher in order to contribute to the rigour of the analysis and avoid possible criticism on the grounds that the research presented here is based on theoretical models which have not been empirically tested (cf. Grisot 2017). In order to test the validity of the most predominant themes about the men represented in the ads that I initially recovered, a group of 10 male informants expressed their level of agreement (5-point Likert scale) on a list of implied meanings for each of the ads analysed.

Last, but not least, this piece of research also has a critical agenda as it aims to assess whether the view of the hegemonic male is still present in the contemporary advertising of grooming products or, whether, in contrast, the representations are illustrative of a more varied myriad of male roles in an attempt to reflect that the times are really changing. Also, by looking at a specific product type, that is, grooming products I will attempt to unveil existing gendered practices which might reveal a stereotypical view of men who consume these products as a group.

\section{Implicatures in advertising and the multimodal construction of represented participants}

This article takes the fact that discourse analysis deals with the implicit meanings contained in a text (cf. van Dijk, 2006) as a starting point in an attempt to unveil the thematic cores of male identities embodied in a corpus of TV ads featuring male grooming products. This will be done by assessing what information is both explicitly and implicitly conveyed, not only about the product advertised but, more importantly, about the represented participants portrayed in the TV commercials. Therefore, the multimodal analysis of a corpus of TV ads carried out here is informed by the pragmatic notion of implicature. Implicatures are normally defined as the specific inferences or weak semantic implications that participants make in a communicative situation on the basis of their understanding of what is said in the specific context (cf. Atlas, 2000; Gazdar, 1979; Grice, 1989; Levinson, 2000).

The role of implicature in advertising has a pragmatic raison d'être as its prolific use allows advertisers to convey certain assumptions about the product, the represented 
participants and the lifestyle(s) to be achieved (Williamson, 1978) through its purchase in an indirect way. The analysis of what is implied rather than explicitly stated in advertising can help researchers unveil its hidden agenda ${ }^{4}$. In this sense, advertising, as part of the mass media, constitutes one form of multimodal 'contemporary communicative manipulation' (Van Dijk, 2006: 361) in which what is said about the product has given way to what is implied about it, thanks to the role of other semiotic modes or meaning making resources. As Geis (1982:50) states:

It should be clear by now why the use of indirect means to convey claims is so attractive to advertisers (and other speakers as well): One doesn't have to defend such claims and consumers are less likely to defend against them than overtly made claims.

Another important reason for the use of implicitness or indirectness in TV advertising is the fact that ads have become shorter with an average length of 15 seconds, compared to an average length of a minute back in the 1950s. Thus, when faced with a $\mathrm{TV}$ ad, audiences are expected to process the information conveyed through the different semiotic choices which make up the ad. The inferential process involves the tying in of new information with already existing beliefs and assumptions in an attempt to make sense of the ad, which is anchored to a specific context. In this respect, when an assumption is implicated or indirectly hinted at, audiences construct new meanings which were never given in the ad (Dick, Chakravarti and Biehal, 1990) and which are much less prone to counterargument (Lee and Olshavsky, 1995) or challenge due to their being 'hidden' (Van Dijk, 2001). That is, they are not explicitly stated and are, hence, only to be attributable to the audience's inferencing abilities. Thus, implicature is especially useful when advertisers want to link the purchase of the product or its consumption with sexual rewards; or when sensitive information regarding stereotyped portrayals of either men or women is subtly conveyed, i.e., when advertisers want to convey the message that women have less confidence in themselves when they age or when their children abandon their home (cf. Author, 2018 under review). However, even if the recovery of implicit assumptions is a phenomenon for which only the viewer is responsible for, it is also true that the range of assumptions to be recovered is limited and can only be accessed within the context in which the ad takes place, and taking into account certain shared assumptions or shared knowledge between advertisers and audiences. Therefore, the implicatures intended to be recovered are a tool of the manipulative nature of advertising, and as such it can be said that we, as viewers of commercials, do not really produce a genuine 'meaning' but rather consume a predetermined solution imposed by advertisers (Williamson, 1978:75).

The Relevance Theory framework, as developed by Sperber and Wilson (henceforth S\&W) $(1986,1995)$, provides the researcher with the necessary tools to assess the implicatures conveyed. Within this framework, implicatures are a way in which relevance and successful communication can be achieved (Moeschler, 2012) and they range from those which are easily recovered, as there is little or no ambiguity as to what the intention of the speaker is or could be, to those which are less accessible and are hence open to debate, i.e., weaker implicatures. Although verbal stimuli are key for the recovery of implied assumptions, the role of visual stimuli in TV ads, as more peripheral meaning making devices, should not be underestimated. In fact, as van Leeuwen states (2008: 137) "if images seem just to allude to things and never 'say them explicitly' we need to make these allusions explicit”.

\footnotetext{
${ }^{4}$ See, among others, Wodak's analysis (2007) of the pragmatic notions of presupposition and implicature in political rhetoric to intentionally convey anti-Semitic prejudice or van Dijk (2005).
} 
What is more, the last few decades have witnessed an unprecedented interest in multimodality as a key aspect for discourse studies (cf. Machin, 2007, 2008; Machin and Myer, 2012; Renkema, 2004), while the discourse of TV ads has become more and more multimodal, with a higher reliance on the visual mode for its interpretation. This makes it necessary to account for the various existing semiotic modes that make up a TV ad if we really want to tackle how the intended meaning of advertisers are conveyed (see Author 2018 under review, 2018 in press, Author, 2013). Thus, in addition to the pragmatic analysis of implied meanings described above and as a complement to it, I will also pay attention to what visual choices advertisers make in the representation of male persona by focusing on how interpersonal meaning is constructed within the framework of visual social semiotics (Kress and van Leeuween, 1996, 2006).

Kress and van Leeuwen (1996, 2006) approach the analysis of visual representations or arrangements drawing on the three meta-functions developed in Halliday's account (2004). Thus, they assigned a representational, interpersonal and compositional/textual meaning to images. For the purpose of this article only the interpersonal dimensions of gaze and framing devices will be considered as potential visual carriers of gender stereotyping (cf. Author 2018, under review). The interactive or interpersonal metafunction is concerned with three categories which illustrate how what is represented in a visual composition interacts with the viewer through the dimensions of (i) gaze, (ii) frame and social distance, and (iii) angle of interaction. Gaze deals with the way interaction is established between the represented participants of the ad and the viewer. Accordingly, there are two types of gaze: 'demand gazes', when direct contact is made with viewers since represented participants directly gaze at the viewer, or through 'offer gazes' in which participants avoid direct contact with the viewer. In the former case, viewers are addressed explicitly with a visual 'you', whereas in the latter, the represented participants are items of information waiting to be scrutinized by the viewer.

Size of frame and social distance refer to the choice between close-ups, and medium and long shots to portray represented participants and objects in images. Goffman's (1979) postulates, based on Hall's (1966) work on the notion of 'proxemics', are that the distances we keep among intimates ('close personal distance') are different from those we keep among strangers ('far personal distance'). Thus, the way different ad persona are presented in terms of frame and distance will index different meanings as to how they should be perceived by the audience, since "distance signifies social relations" in pictures as much as in real life (Machin and Mayr, 2012:97).

\section{Corpus selection and Methodology of analysis}

Corpus selection has been driven by product type and brand popularity in terms of revenue. With regard to the brand value of the top ten leading personal care brands worldwide in 2017, L'Oréal has been found to be at the top of the ranking with Nivea for Men and Clinique occupying the fifth and seventh positions, respectively. This makes them three of the major male grooming brands of beauty companies both for male and female products. Thus, the corpus of analysis is made up of $26 \mathrm{TV}$ ads which advertise toiletries (men's bath and shower, deodorant and skin and hair care) and shaving products for men from L'Oréal Men Expert (L'Oréal), Nivea Men (Beiersdorf) and Clinique for Men (Clinique). In order to select the ads, I have resorted to Advertolog - an advert archive with more than two million ads in its database, which can be retrieved by applying different filters, such as TV or print ads, country and language of origin, brand or product type and year of emission. In particular, the ads selected were those stored from the brands 
above mentioned for a period of seven years (2010-2017) from English-speaking countries such as the USA, the UK, New Zealand and Australia.

As for the methodology carried out in this paper, I have followed a mixed-methods approach (Tashakkori and Creswell, 2007). In other words, the qualitative analysis involves the description of the most recurrent thematic cores identified in the ads and will be of a multimodal pragmatic nature, as I will focus on the verbal message as the basis for the recovery of some pieces of information which are implied or indirectly conveyed. Likewise, the visual representations of male participants will be analysed as meaningmaking semiotic resources which can also aid the recovery of certain implicated assumptions about the product and its users.

The quantitative part of the study involves the empirical testing of the implicatures initially recovered by me and a colleague after watching the TV ads three times. Implicatures, I claim, are likely to be perceiver-dependent and the list of implied assumptions assessed is included in Appendix I.

Ten male informants, unaware of the aims of the article, were instructed to watch the ads and express their level of agreement regarding a number of implied assumptions for each of the 26 ads assessed using a 5-point Likert scale. The scale ranges from strongly agree (1) to, (2) agree, (3) undecided, (4) disagree and (5) strongly disagree. In order to assess the degree of inter-examiner reliability I have provided a description of the following items: median, standard deviation and mean values for each of the items assessed. Those items or assumptions which obtained mean and median values close to $1-2$, and which have a low standard deviation value are highly interpretable as displaying a significant degree of inter-examiner agreement. Likewise, the percentage of agreement amongst examiners has also been calculated. In other words, the scores of examiners 1 and 2 were compared for all the items to be assessed in each ad, then the scores of examiner 1 and 3, then those of examiner 1 and 4, and so on and so forth, to finally calculate the total percentage of coincidences for all the items assessed. The final step involved the bundling of the different implied assumptions into topical categories. That is, those implied assumptions which tackled similar aspects in their projection of male identities were grouped together and qualitatively and quantitatively described in the results section as resulting from both an inductive and deductive procedure. Table 1 below illustrates the different ads which make up the corpus of analysis:

\begin{tabular}{|c|c|}
\hline NIVEA FOR MEN & L'ORÉAL \\
\hline 1. Nivea Men Originals: Life Hacks & 14. Get your Game Face On with L’Oréal Men Expert \\
\hline 2. Nivea Men Crème: Lumberjack Competition & 15. Hydra Energetic Skin starring Lewis Hamilton \\
\hline 3. Nivea Men_Active Charcoal & $\begin{array}{l}\text { 16. L’Oréal Men Expert Hydra Energetic Skin \& Stubble } \\
\text { Decembeard. }\end{array}$ \\
\hline 4. Nivea Men Originals: Forget complicated & $\begin{array}{l}\text { 17. L’Oréal Men Expert Pure Power Charcoal Wash Official } \\
\text { TV Advert manpower. }\end{array}$ \\
\hline $\begin{array}{l}\text { 5. Nivea Original Life Hack: How to open a drink without } \\
\text { a bottle opener. }\end{array}$ & 18. Lewis Hamilton - L'Oréal Men Expert Hydra Energetic \\
\hline \multirow[t]{2}{*}{ 6. Nivea Body Lotion for Men. } & 19. New L’Oréal Vitalift 5 feat. Hugh Laurie \\
\hline & 20. Hugh Laurie - L’Oréal Paris - Men Expert Vita Lift \\
\hline $\begin{array}{l}\text { 7. Nivea Original Life Hack: Keep cake super fresh for } \\
\text { days }\end{array}$ & $\begin{array}{l}\text { 21. Get Tough with Hydra Sensitive Skin Range starring } \\
\text { Marlon Teixera L'Oréal Men Expert }\end{array}$ \\
\hline 8. Nivea for Men_ Shaving & CLINIQUE \\
\hline 9. Nivea for Men: Road to recovery & 22. Clinique For Men Anti-Age Skincare \\
\hline 10. Nivea Originals Life Hacks: punctured football & 23. Clinique For Men Normal-Dry Skincare \\
\hline 11. Men! This is your Crème & 24. Clinique For Men Oil Control Skincare \\
\hline 12. Nivea Ice Mud Serum: Would you fix it like lady? & 25. Clinique For Men The Perfect Shave \\
\hline 13. Nivea Men Crème: The Double & 26. Clinique For Men There's a science to looking good \\
\hline
\end{tabular}




\section{The critical analysis}

Before turning to the qualitative analysis of the different topical categories of male identities identified, I will comment on the quantitative results obtained from the statistical tools applied in order to contextualize their relevance in relation to the topical categories found. First of all, the statistical tools employed have indicated that the percentage of agreement amongst all the pairs of informants on the 166 implied assumptions empirically tested in the 26 TV ads (see Appendix I) was $74.3 \%$. In other words, the ten informants have displayed a high level of agreement in their assessment of the different implied assumptions which were conveyed (with varying degrees of explicitness/implicitness) in the ads which made up the corpus. With regard to the three brands under assessment, the percentage of agreement was $74.1 \%$ for Nivea, $72.8 \%$ for the L'Oréal ads and $76.9 \%$ for Clinique. As indicated in the methodology, on a more specific level, the mean, median and standard deviation scores were calculated for each of the items under analysis. The mean scores for the 166 items assessed range from 1.0 to 2.8, hence signalling a high degree of inter-examiner agreement on the different items assessed. Thus, the closer the mean values of the implicatures assessed are to 1.00, the higher the chances of their being recovered by audiences. That is to say, these implied assumptions would certainly be more accessible and attributable to the intention of the advertiser. In contrast, those implicatures with mean values closer to 2.5, would be less easily recovered and, thus, conveyed in an indirect way, so it is the viewer who takes the largest share of the responsibility in recovering them ${ }^{5}$.

The most predominant male identities portrayed and encapsulated in the different thematic cores that emerged after the analysis of the 26 ads are described below. The topical categories most recurrently touched upon are: (i) the gender divide; (ii) sexual power through product consumption, (iii) reaffirming manpower through manly activities and (iv) the savvy modern young man. The key implied assumptions which lie at the backbone of each thematic core will be illustrated together with other implicatures which, despite being ad specific, also aid in the transmission of a certain male identity.

For their part, the thematic cores identified may exceptionally include ads from just one brand, or, on the contrary, be made up of ads from two or even from the three brands under analysis. The distribution of ads per topical category is as follows:

\footnotetext{
${ }^{5}$ In spite of this, it was not the aim of this article to assess the degree of explicitness/implicitness of the implied assumptions recovered in each ad. Rather, the results from the statistical tools should be viewed as a first diagnostic step which has backed up the researcher's intuitions in the recovery of implied assumptions and which has, in my opinion, added rigour to my own analysis and to the subsequent process of classification of implicatures into topical categories.
} 


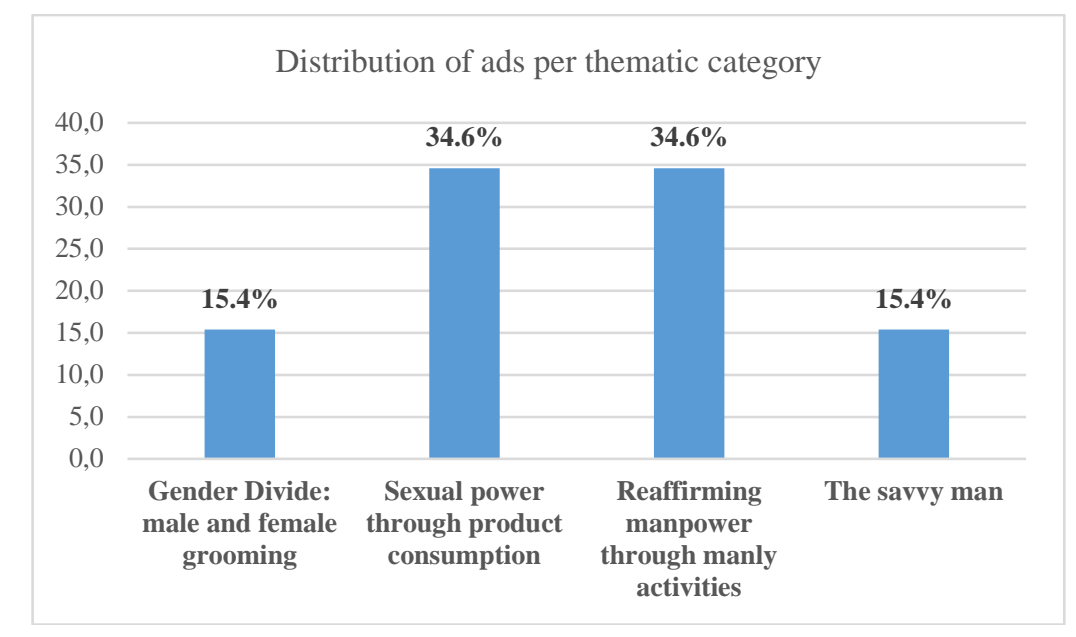

Figure 1. Ad distribution per topical category

The Gender divide: Men groom like real men and not like ladies

The percentage of ads which deal with this topic is $15.4 \%$. Into this thematic core fall four of the Nivea ads (ads 4, 9, 11 and 12) that aim to present the general idea that masculinity and femininity stand on opposing ends, thus embodying the polarization theory which views certain attributes as being either only masculine or only feminine (Stern, 2003: 223). These ads aim to demarcate the masculine and the feminine way of using grooming products with a tongue-in-cheek attitude in order to get the following message across: "we, men, groom like real men and not like ladies". Thus, the gender divide: 'us' and 'them' is emphasized through the implicature "men and women groom in a different way (ad 11, mean=1.5, $\mathrm{SD}=0.5$; ad 4, mean=1.6, $\mathrm{SD}=0.5$; ad 9, mean=1.6, $\mathrm{SD}=0.5$ and ad 12, mean=1.7, $\mathrm{SD}=0.7$ ), which lies is the backbone of this topical category.

Accordingly, the Nivea for Men ad 'Road to Recovery' (ad 9) exploits the stereotypical view that women's face care is different from men's face care (mean=1.6, $\mathrm{SD}=0.5$ ), thus tapping onto the widely held belief that clearly divides men and women's grooming routines into those which take longer, that is, women's, and those which are, as Nivea states, "more evolved skincare", and take up less time (mean=1.9, $\mathrm{SD}=0.6$ ). Table 2 below illustrates the different shots that make up the ad and the information provided by the male voice-over as key for the recovery of the implied meanings about men who groom:

\begin{tabular}{|c|c|c|}
\hline $\begin{array}{c}\text { Frame- } \\
\text { time }\end{array}$ & Image shots & Voice-over \\
\hline $\begin{array}{l}1 \\
00.00-00.03\end{array}$ & & $\begin{array}{l}\text { For some, recovery is } \\
\text { a long road. }\end{array}$ \\
\hline $\begin{array}{l}2-3 \\
00.03-00.04\end{array}$ & & $\begin{array}{l}\text { [male voice-over]: } \\
\text { For men }\end{array}$ \\
\hline
\end{tabular}




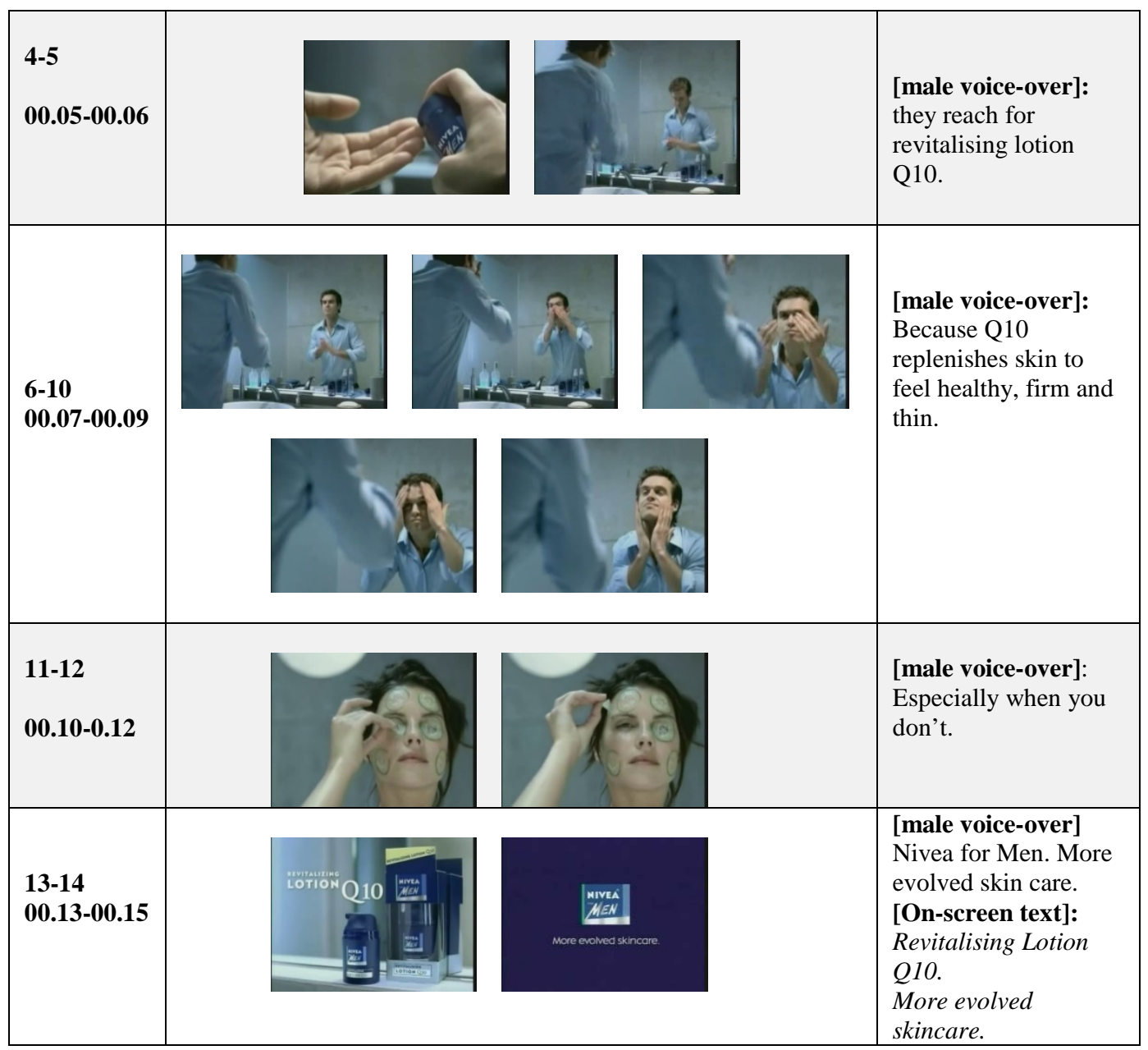

Table 2. Nivea for Men 'Road to Recovery'.

The Nivea for Men 'Road to Recovery' ad starts with the shot of a young woman lying down in the tub with slices of cucumber on her eyes and the explicated assumption "For some recovery is a long road". Although the noun to which "some" makes reference could be initially unclear, the audience immediately assigns personal reference to the expression and can then recover the assumption that recovery takes longer for women as compared to men. As the voice-over states, men reach for Nivea Q10 with the presupposition that women don't, as visually reinforced by the image of the girl who has resorted to other forms of 'recovery'. What is more, the voice-over provides the rationale for using the lotion (shots 6-10): that is, it replenishes skin to make you feel healthy, firm and thin, especially when you don't feel that way. At this point, the audience is forced to look for an interpretation of such an explicated premise. As such words coincide with the shot in which the girl removes one of the cucumber slices from one of her eyes as if feeling alluded to, it could be inferred that women, or at least the woman in the ad, doesn't feel healthy, firm and thin especially after going through a rough situation. It should be noted that this implied assumption, albeit relying on verbal information for its recovery, has been perceived as weak by the informants (mean=2.5, $\mathrm{SD}=0.8$ ). Finally, the audience is faced with the explicit assumption: "Nivea for men. More evolved skin care", from which we are invited to recover that Nivea is more evolved skin care than that provided by other brands (mean=2.4, SD=0.7). But why not? One could also derive the weaker implicature that men's grooming products are more evolved than women's in view of the mini-drama presented (mean=2.4, SD=0.7). In a word, women's ways of doing things are not as evolved as men's ways, and certainly the ad visually hints at the fact that men are 
more intelligent than women for using a simpler way of taking care of their face (mean $=2.3, \mathrm{SD}=0.8)^{6}$. From a visual point of view, the man in the ad also looks confident and happy after using the product (mean $=1.9, \mathrm{SD}=0.6$ ). In any case, the visual contrast is clear, as the girl is lying down, performing no activity, while the man is actively putting on the cream, already looking replenished and fabulous, while she has to go through all this trouble to look fantastic.

The Nivea Men Originals: Forget Complicated (ad 4) also dwells on this gender divide, by explicitly stating that men's face care is not the same as women's face care. Such a bold-on-record assertion is mitigated through visual justification as the narrative unfolds through a montage, by presenting a series of extreme situations in which men are trying to behave like women: we see how a man exiting the shower in a male changing room looks with stupor at other men who are lying down on chairs while having masks on their faces and drinking sodas. As face care is traditionally a female activity, the audience is invited to bring this background knowledge into the inferential process to be carried out. Hence, the implicature to be recovered by looking at the males' faces is that the situation (men attempting to groom like women do) is not 'normal' or 'typical' of male grooming (mean=2.0, $\mathrm{SD}=0.5$ ), hence visually reinforcing the already known stereotype. Another implied assumption recovered from the visuals in the ad (we see how a girl is getting impatient while having to wait for her boyfriend as he is getting all dolled up in the bathroom, or how a man is trying to wax his beard off his face, while a lady at the saloon shakes her head in disapproval) is that women's face care is time-consuming and complicated (mean=1.5, SD=0.5). By jokingly presenting men attempting to groom like ladies, the ad aims to convey that male grooming does not have to be so messy. In fact, moisturizing can be not only simple, an aspect that is reinforced by written information on the screen (71\% of 164 men agree, thus presupposing that quite a large percentage have tried it), but also fast and feel good, as part of what is explicitly conveyed. In order to justify such claims, the visual narration depicts a young attractive boy who applies the lotion in one second, checks himself in the mirror and walks confidently down the street, where a young attractive girl gets distracted by his looks and crashes her car into the one in front of hers. Thus, it is implied that men value simple and fast skin care (mean=1.6, SD=0.7). Close-ups or close shots are employed when the boy is engaged in his quick face care routine, but he never looks at the audience, and hence, he is presented as an object for contemplation. The implicature that if you wear this lotion you'll get noticed, especially by the female population, is reinforced visually in this mini-drama (mean=1.4, SD=0.5). A weaker implicature refers to the fact that young women may like men who groom and take care of themselves, and feel attracted to them (mean 2.0, $\mathrm{SD}=0.7$ ), to the point that they can even get distracted from other activities such as driving.

For its part, the Nivea ad "Men! This is your Crème" (ad 11), features a bunch of Real Madrid Players (i.e., Carvajal, Marcelo, Isco and Bale) as examples of real men who display a medium level of activity. These real men are depicted as entering a typical American bar where different men hang out, while heavy rock music is played in the background. The moment they step in, a tough muscular guy looks up at them defiantly.

In the next shot, one of the players is engaged in arm wrestling with the muscular guy while another of the real men stands up arms crossed with a menacing look on his face. When the soccer player wins, a harsh masculine voice over informs us that "Real Men live life to their own soundtrack". The audience is invited to assign reference to the

\footnotetext{
${ }^{6}$ It should be noted that all these implied assumptions have obtained higher mean values, thus indicating that they are conveyed in a weak or more indirect way, considering that they are deployed through verbal but above all visual stimuli.
} 
expression "real men" and identify them with the soccer players depicted, as men who engage in manly activities in a typically male scenario, such as a bar where no women are present and where men 'fight' other men. What is more, by explicitly talking about "real men" the male audience is indirectly asked to decide whether they belong to the group of real men or not. In the next shots, the players are depicted driving in a car towards what looks like the eye of the storm, while attempting to avoid different objects the tornado is lifting up into the air while their faces remain serious and unreadable. The visual implicatures prompted by the explicit assumption conveyed by the voice-over is that real men are 'tough' (mean=1.7, SD=0.7), and face adversity with determination (mean=2.0, $\mathrm{SD}=0.7$ ). The four participants never address the audience directly till the end of the ad. Rather, throughout the mini-drama they are rather presented as objects for contemplation, as specimens belonging to a group, that of real men in combination with medium and close shots. The fact that close shots are employed allow the audience to closely examine their 'stern faces' or 'hard looks', which for Nixon (1996) was a way of showcasing masculinity and toughness in the printed media.

With regard to their body language, the male persona portrayed adopts stand-off poses (Bordo, 1999) hence, sending off the message that they are fierce and it is better not to mess with them. The voice-over further states "So when you skin needs care, don't change the music". The use of "so" facilitates the inference that when you need a skincare, presupposing that at some point you will need it, you have to do it the male way, which is different from the female way of grooming (mean $=1.5, \mathrm{SD}=0.5$ ). The male persona in this ad somehow conforms to Thompson and Pleck (1986)'s view that men should be emotionally and physically tough and self-reliant, while also avoiding activities which are stereotypically feminine. In fact, the sudden change of music in this ad (from the heavy metal to a more melodic vocal and feminine tune) as they open their locker and find a bunch of pink toiletries for women invites to infer that that men groom but want a certain detachment from such activity, as evidenced by the frown in their faces. In this respect, Nivea can help you groom but not like a woman would do (mean 1.9, SD=0.7).

The combination of these visual choices portrays men as part of a group, in a way that collectivises them, while conveying the idea that these men are willing to stand up for each other and to remain united in the face of adversity, as evidenced in the minidrama narrated, especially when it comes to the consumption of grooming products.

Likewise, the ads under this category have attempted to construe masculinity and femininity as different through the colours employed to depict the product advertised, through the colours that the male participants wear or through the colours that pervade the background images in the ads. Thus, there is a notable absence of the traditionally feminine colours (pinks, mauves, purples) and a predominance of blues, together with dark colours such as greys and blacks. These colours, as Caldas-Coulthard and van Leeuwen (2002:101) have pointed out, "attach values to the idea of masculinity”.

\section{Male sexual power through product consumption}

Into this thematic core fall those ads which link the consumption of the product with sexual rewards for the male represented participants with varying degrees of explicitness/implicitness through verbal and visual stimuli. This category comprises $34.6 \%$ of the ads analysed and includes ads from the three brands under analysis. The ads are Nivea's ads 2, 3, 6; L’Oréal ads 16, 18, 19, 20, and Clinique ads 22 and 24. The overall implicatures are that, just like the male participants represented in the mini-dramas, men who consume the product will also be able to attract female participants (ad 2, mean=1.9, $\mathrm{SD}=0.6$; ad 6, mean= 1.8, $\mathrm{SD}=0.6$; ad 16, mean=1.9, $\mathrm{SD}=0.6$ ), even if they are past their 
40s (ad 20, mean=1.7, SD=0.7). Likewise, it is implied, albeit in a weaker way, that the men who consume such products will know how to please a woman (ad 3, mean $=2.5$, $\mathrm{SD}=0.5$ ). Other ads put the onus on male sexuality as a male defining trait (ad 23, mean=1.6, $\mathrm{SD}=0.7$; ad 24 , mean $=1.7, \mathrm{SD}=0.5$ ) aided through product consumption.

In contrast, female persona are portrayed in these ads as a reward for the consumption of the product, with the advertiser somehow putting the focus on a heterosexual relationship as normative (cf. Connell, 1987) while also sending off the message that women value men who groom and take care of themselves (cf. Scheibling, 2014 for similar insights in her analysis of printed grooming ads for men). For example, in ad 2, a young lad receives the approving looks of a girl as he wins a lumberjack contest with two guys whose physical strength and sturdiness are more than patent, while operating a power saw to cut a log and not getting any of the shavings on his skin thanks to the non-greasiness of Nivea crème.

This ad reclaims masculine traits by positioning the man in an activity which has been traditionally thought of as manly (mean=2.0, SD=0.8) (cf. Brandth and Haugen, 2000) and invokes notions of male toughness and willingness to compete with others, while also focusing attention on the use of the power saw as a manly tool (cf. Follo, 2002). Thus the men in the ad have been perceived as strong and determined (mean=1.7, $\mathrm{SD}=0.7$ ), while toughness (mean $=2.0, \mathrm{SD}=0.8$ ) is one of their defining traits.

Ad 20 employs a lecture format in which Hugh Laurie demystifies the passing of time for men by sending out the message that men should keep a positive attitude as they age (mean=1.7, $\mathrm{SD}=0.7$ ), and be themselves with the aid of the product (mean=1.6, $\mathrm{SD}=0.7)$. His positive tongue-in-cheek attitude conveys the implied assumption that men do not do crazy things when they age (i.e., panic, become spiritual, or go on a diet, write your life story, use the knife, rediscover your youth, etc.,) (mean=2.1, SD=0.7), probably as they are not highly concerned about their ageing. Although only two ads tackle the ageing issue in the corpus, this finding seems to tie in well with research that has found that men view ageing-related changes in their appearance as less threatening in comparison with women (cf. Halliwell and Dittmar, 2003). The presence of a woman, definitely younger than he, who kisses him in the car, helps to convey the assumption that men in their 40s are still attractive enough for younger women (mean=1.7, SD=0.7), as they only need to revitalise their skin, with the presupposition that their skin is full of vitality. Rather than being concerned about skin issues, men are portrayed as having the right to enjoy life to the full (mean=1.6, $S D=0.7$ ). The visual choices in this ad index meanings of men as engaged in an activity, as it should be noticed that the male celebrity lectures the audience in the role of expert, while the women represented are secondary characters supportive of the male persona in a secondary place (the home in this ad) and not engaged in any purposeful activity except for that of having packed the suitcases before getting in the car.

In addition, two ads in the corpus deal more explicitly with the topic of male sexual potency, as the female represented participants become key figures in the minidramas portrayed. They are the L'Oréal Men Expert Hydra Energetic Skin \& Stubble Decembeard (ad 16), and the Nivea Men Active Charcoal (ad 3).

Ad 16 (see Table 3 below) presents the product not as the solution to an appearance-related issue, but rather, as a sexiness enhancer. In fact, the audience is asked whether they want to be sexy and then offered a solution: if you want to increase sexiness all you have to do is to get a barber shop experience. The experience comes in three lessons while simplicity is being highly valued and emphasized (mean $=1.5, \mathrm{SD}=0.5$ ). It should be noted that the need to groom oneself is not problematized in some of these ads, 
in contrast to what has been found in Author (2018 under review) or in previous research by Ringrow (2016).

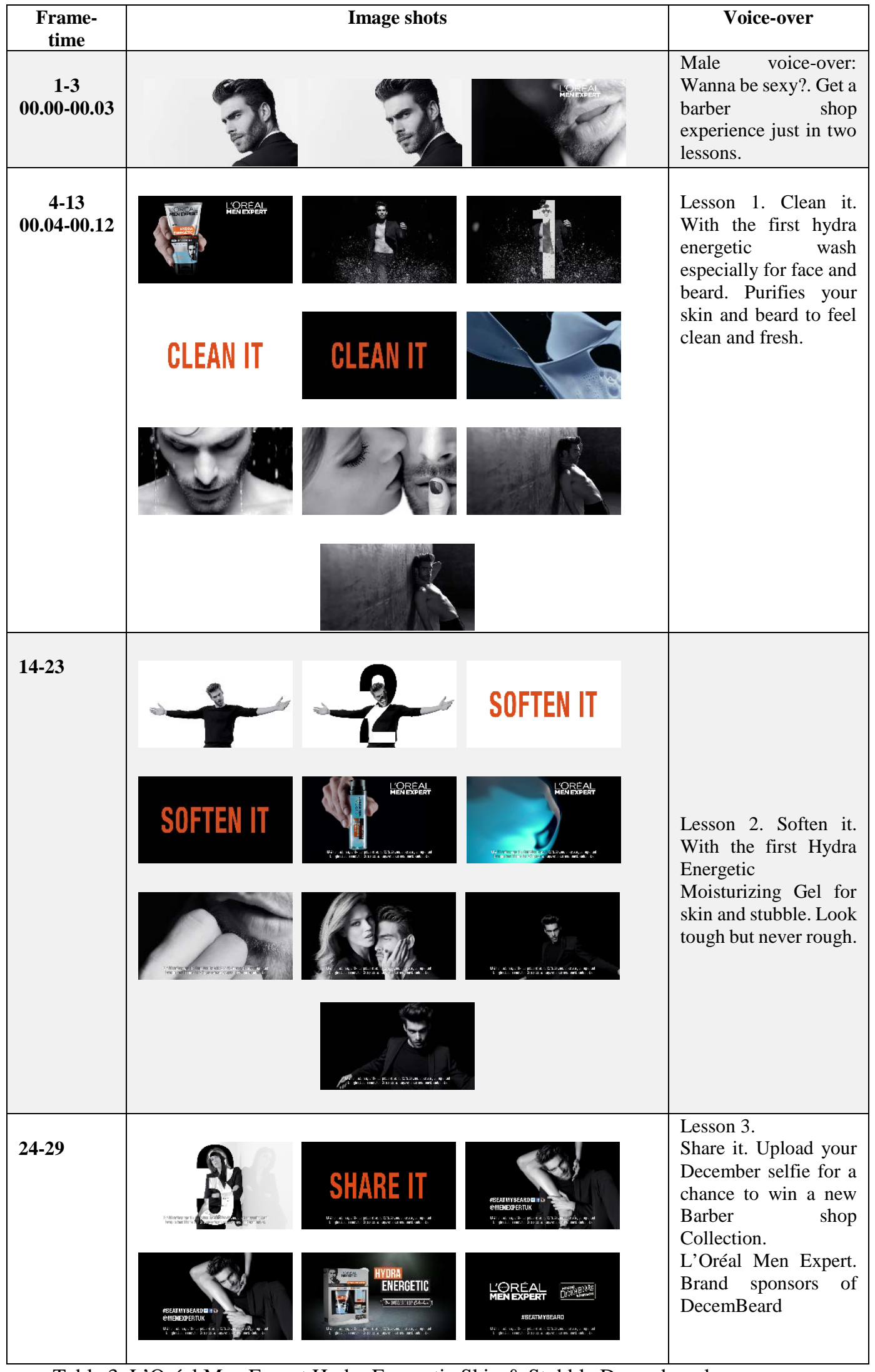

Table 3. L’Oréal Men Expert Hydra Energetic Skin \& Stubble Decembeard. 
While the voice-over instructs the potential customer with the different steps to follow in order to get the barbershop experience, the visual mini-drama portrays a female character, in all of the three stages recommended in the ad: kissing the man's lips around his beard in the first one, caressing the men's beard once it's been softened, while looking at the audience in a seductive way (mean=1.6, $\mathrm{SD}=0.7$ ), as part of the second step, and finally, leaning on the wall and again provocatively looking at the audience while slightly tilting her head to one side (Goffman 1979) as if sexually aroused. The audience is in this stage informed that the new step to get a barber shop experience is to share your beard, presumably with a potential female persona and then what we get is a close-up of the man caressing the woman's long legs. He looks at the audience with a wicked smile suggestive of his sexual achievement. For her part, the woman has been dismembered in shots 2627 as only her long legs are displayed, hence visually drawing attention to one highly eroticized female part (mean=2.0, $\mathrm{SD}=0.7$ ), while the male figure occupies the lower space of the close-up. The ad then urges men to upload a picture of their beards for a competition, thus invoking another traditional male trait. In a way this ad visually conveys the idea that women will feel more attracted to you and will desire to kiss your beard (mean=1.9, SD=0.9), if you use the product advertised. The intimacy which emanates from the mini-drama is aided by the use of demand gazes, which seem to invite the male recipient into an intimate relationship while perhaps also challenging him to try the product together with framing through medium and close-ups. The lack of discernible background in the ad and the lack of agency on the part of both participants puts the focus on their relationship, as the key reward to be obtained. The way the male participant leans against the wall while turning his head towards the camera, as an object to be eroticized and consumed (Gill et al., 2005), is also reminiscent of eroticized female images so pervasive in the advertising of perfumes and in advertising in general. What is more, we get shots of male body parts, such as lip area, or lips parted in shot 3 , together with the naked torso, while the male participant seductively looks at the audience (mean=1.6, $\mathrm{SD}=0.7$ ) (this is also the case in ad 21 , mean $=2.0, \mathrm{SD}=0.8$ ).

Likewise, ads 3 and 6 employ sexual innuendo at a visual level. In ad 3 different men are depicted in extreme situations while manipulating different tools as part of their manly blue collar jobs, thus signalling a high level of activity on their part. The voiceover states "Real men use the right tools for the right job", thus visually conveying the implicature that men are skilled at the manipulation of tools (mean=1.9, SD=0.7), efficient at problem solving $(2.0,0.8)$ and not afraid of situations which may involve risk or difficulty (mean=1.6, SD=0.7), such as the ones portrayed in the ad. However, the ad ends with the image of a man who has just got out of the shower after using the Nivea shampoo to eliminate dirt and who walks towards a woman lying on a bed while loosening his towel to reveal his naked genital area. The voice-over says: "Always use the right tools", as if weakly and visually implying that the man in the ad is also seen as skilled at using his manpower with a woman in bed (mean=2.5, SD=0.5). Visually, the man in this ad is depicted as tough and well-built and, accordingly, this ad touches upon the belief that masculinity is a matter of the body (Kimmel, 1996) and thus, masculinity is expressed through physical strength, which in this case, is visually and indirectly equated to sexual prowess. As was the case with other ads (ads 2, and 16), the visual choices which present the woman lying on bed, while waiting for the man who has been previously engaged in physical activity index meanings of normative labour divisions in which women are best seen as a reward for men, after what is, in this case, a job well done. What is more, while men are portrayed in a clear and defined activity, women are not, thus fulfilling a passive or decorative role (Plakoyiannaki and Zotos, 2009). This is also evidenced in ad 6 where 
a hot sexy girl is waiting for one of the male represented participants depicted in the ad after their work-out session at the gym.

Achieving and reaffirming manpower through manly activities and the quality of being tough

Into this thematic core fall different ads in which manpower is reaffirmed and/or reframed through reliance on stereotypical constructs which view men as sport supporters, with soccer as the preferred sport, or which emphasize the fact that men like cars, while also highlighting their quality as 'being tough' but never 'rough'. The ads under this thematic core are the Nivea ads 8, and 13, the L'Oréal ads 14, 15, 17, 18 and 21 and the Clinique ads 23, 25 and 26 and they comprise 34.6\% of the ads in the corpus.

In this repertoire, some of the ads feature well-known soccer players such as Australian Chad Wingard (Port Adelaide Football Club) and David Zaharakis (Essendon Football Club), or British Formula One racing driver Lewis Hamilton and they stress men's physical strength and toughness. Not in vain, as Katz (2003:355) states, the use of boxers or soccer players together with athletes constitutes one of the ways to sanction the masculinity of what can be a suspect product. In this respect, the use of grooming products, which fall within a traditional female arena, is endorsed by prototypical male figures, whose physical size and strength are remarkably above average, while also being a symbol of their masculine power. Not in vain, hegemonic masculinity is more than often intertwined with athletic skill (cf. Wheaton, 2003)

One of the ads in this thematic core is the L'Oréal Expert ad 'Get your game face on' (ad 14) described below in table 4:

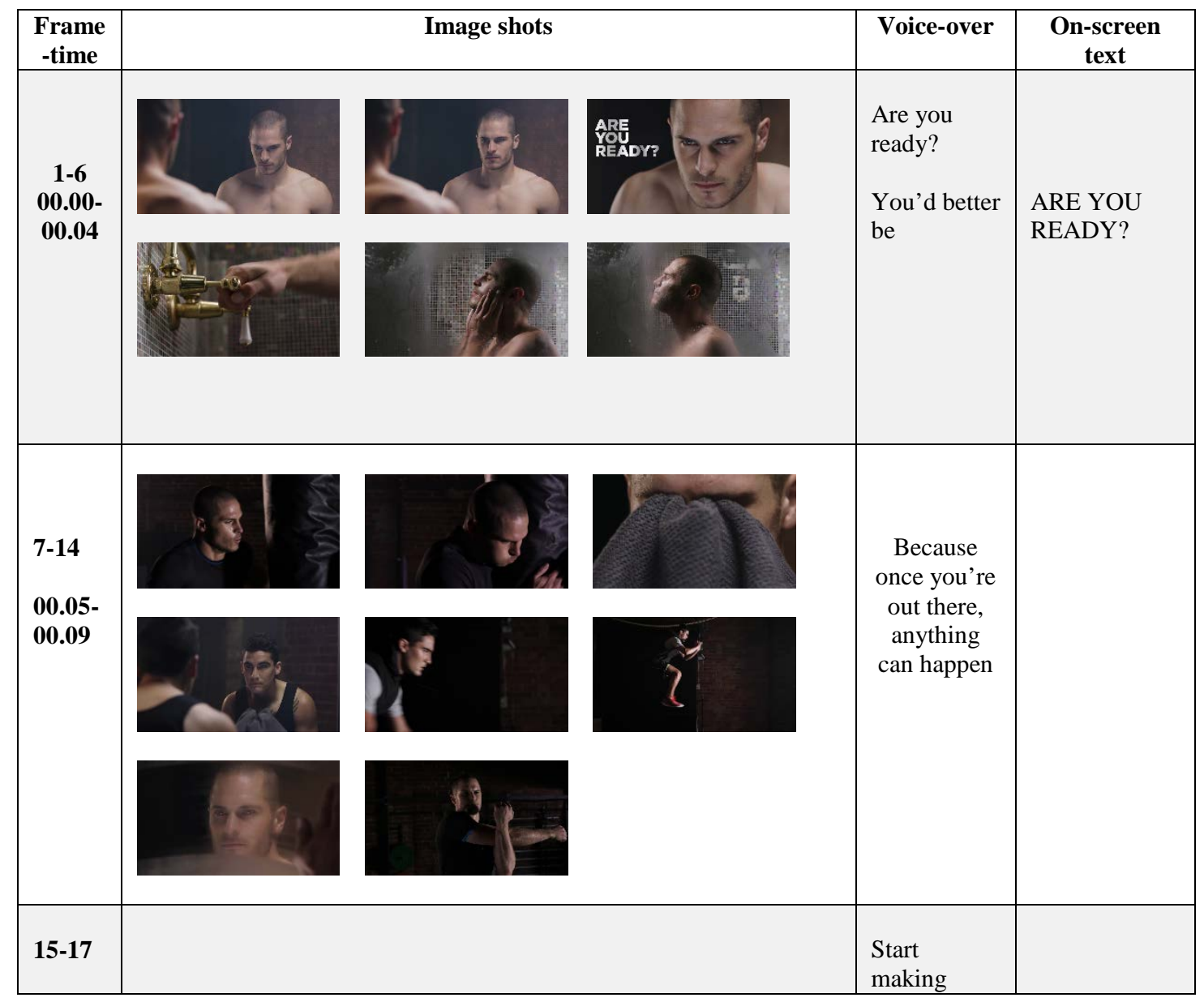




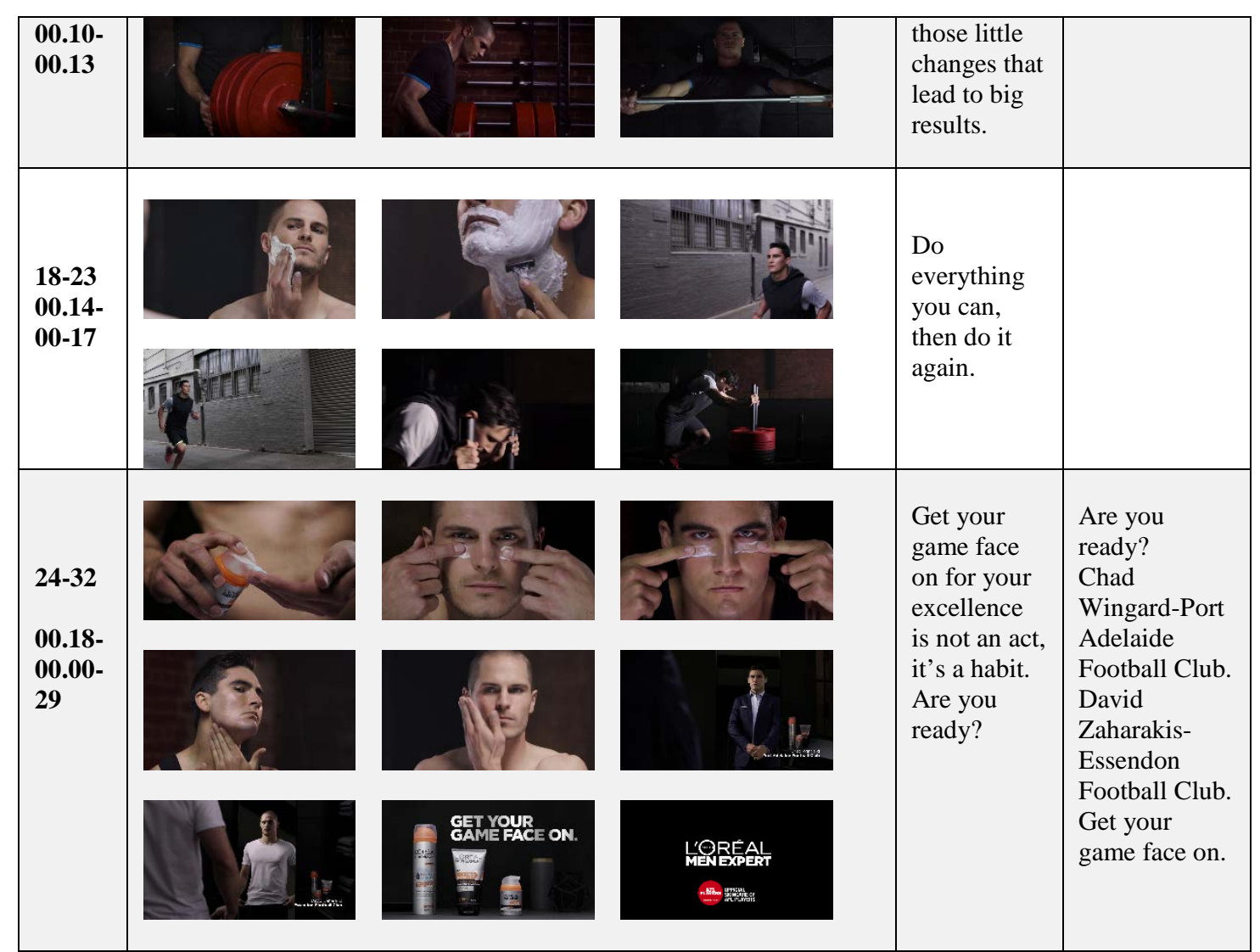

Table 4. 'Get your game face on'

The ad begins with a male voice-over that directly addresses the male audience in a military style while posing the question 'Are you ready?', following this inquiry with the piece of advice 'You'd better be' while we see close-shots of soccer player Chad Wingard looking at himself in the mirror with a grave face, and then turning on the shower tap while gently wetting his face. The menacing tone of such a piece of advice presupposes that men should be ready "because once you're out there, anything can happen”. However, by combining such explicit premises with the visuals in the ad, we realise that men are urged to be ready for tough situations or activities, such as those experienced by the Australian players in the ad. Among such activities, a parallel is established between the hard training these two sportsmen undergo every day (weight lifting, sack punching and jogging) and the daily routine of shaving. At some point, the voice over states "Get your game face on for your excellence is not an act, it's a habit", thus presupposing excellence in the activities they undertake while also making use of a quote from Aristotle which emphasizes the importance of repetition in achieving habits. What is more, getting the game face on is visually reinforced by shots in which the two players apply the L'Oréal cream on their faces in the Aborigine style, as if ready to fight, and looking directly at the viewer with a demand face that seems to invite and or challenge the male audience into the game. The weaker implied assumption here is that men have a warrior inside them (mean=2.0, $\mathrm{SD}=0.8$ ), which somehow confers manly traits to the act of moisturizing one's face after having. Further implicatures point to the fact that men are tough and strong (mean=1.6, $\mathrm{SD}=0.7$ ) and creatures of habit whose resilience and insistence makes them excel in whatever they do (mean=2.1, SD=0.6), whether it is their shaving routine or any other physical activity. From an interpersonal point of view, body parts such as a naked torso and arms or a bare chest are displayed in the shots while the male persona is working out. However, rather than being depicted as a sex objects, it 
seems that the fact that they are athletes legitimizes the display of the male body and body parts as a contemplation object for the 'male gaze' (cf. Morse 1983 for a similar insight into the display of the male body in sports). Thus, such visual choices through close-ups and demand gazes seem to index meanings of physical strength and resilience, while also reinforcing male prowess.

On their part, ads $8,15,18,17$ and 21 , deal with the manly quality of being tough as prescribed by hegemonic views of masculinity (Connell, 1995) together with domination over others, and the quality of not being afraid of risky activities, as the skill of risk management is thought to be an asset of masculinity (Morgan, 1992). The L'Oréal ads 15 and 18 feature formula one driver Lewis Hamilton to advertise a hydra-energetic body and face moisturizer and have as their motto the line "Get tough but never rough". From some of the explicated assumptions such as: “Gentlemen, we can't promise we'll make you a better driver or a rock star. And it won't increase your pulling power. [Lion roars])", together with background knowledge and shared beliefs about advertising normally being tricky and deceptive, the audience is invited to recover the implied assumption that the brand is being truthful and does not want to entice us into believing that we will become something we are not just by using the product (mean=1.8, $\mathrm{SD}=0.8$ ) and that it is made by experts (mean=1.9, $\mathrm{SD}=0.9$ ), as it is endorsed by well-known celebrities.

On the other hand, the celebrity addresses the audience to encourage men to use the product, with the promise “you won't be more buff but you will look less rough". The presupposed assumption is that men are already buff, as we see the driver doing his pushups in the gym, and that they can look rough when their skin is not moisturized. Thus, it is implied that using the product will make you feel and look refreshed (ad 18, mean=1.5, $\mathrm{SD}=0.5$; ad 15 , mean $=1.3, \mathrm{SD}=0.5$ ), thus making face care routine simple and hassle-free (mean=1.6, SD=0.7). Weaker implicatures indirectly and visually aim to convey that men are as strong as lions (mean=2.5, $\mathrm{SD}=0.7$ ), as a roaring lion is shown when the male voice- over informs us that using the product won't increase men's pulling power, hence, presupposing that men have pulling power, and are capable of attracting women on principle. By just mentioning this, while showing a Lewis Hamilton surrounded by young sexy girls, the ad indirectly tackles the stereotypical view of male celebrities as female magnets as women will feel attracted to them (1.6, SD=0.5).

For its part, Clinique ad 23 explicitly makes a comparison between washing one's face and playing soccer. By bringing up a manly topic and juxtaposing images of a black man's body kicking a soccer ball and those of a goalkeeper aiming to stop the ball, the ad sets up a more receptive atmosphere while taking for granted that the potential audience is familiar with this kind of talk: "Just washing your face is like playing football. With only your strikers, you need mid-fielders to rough up the guys that will make it to your forwards and of course, you need to protect the goal. Cleanse, exfoliate, moisturize, it takes a team to win. Get ready to score. There's a science to looking good.” By talking "soccer language", the ad implies that men who use the product are knowledgeable about this sport, while also implying that with Clinique looking after one's skin is easy (mean=1.8. SD=0.6). Likewise, the expression "get ready to score" is meant as an implicit piece of advice to be ready to sexually attract a partner, thus recurring to male's sexual power as a benefit from the product use (mean 1.6, $\mathrm{SD}=0.7$ ). Ad 25, for its part, resorts to the topic of driving and men's fascination with cars. Belk (2004: 273) justifies such a passion "given the association of such vehicles with power, danger, mobility, status competition, and industrial dominance over nature, all of which are stereotypically male fixations as well”. The mini-drama is made up of shots of a car being driven on a wet road juxtaposed with shots of men involved in the routine of shaving, while the audience is 
instructed on how to shave by a male voice-over: "first warm it put, then clear the path, when it's wet and sleek control our speed around the curves, when you're done make sure you're covered. There's a science to looking good. 1. Scrub, 2. Shave, 3. Soothe”. From the visuals together with the explicatures, it can be inferred that shaving can be a hasslefree activity (mean=1.5, $\mathrm{SD}=0.7$ ) just like driving. What is more, the ad implies that men like to drive (mean=1.8, $\mathrm{SD}=0.6$ ), and that modern men look after themselves (mean=1.4, $\mathrm{SD}=0.5$ ) and are confident about their looks (mean=1.5, SD=0.7) as they look directly and seductively at the audience (mean $=1.5, \mathrm{SD}=0.5$ ), while also emphasizing that albeit simple, there is a science behind looking good (mean=1.8, $\mathrm{SD}=0.8$ ). The male participants display a very low degree of activity, as they are merely portrayed using the product but still look intently at the audience.

\section{The Savvy modern young man}

The last thematic core encompasses several ads from Nivea (ads 1, 5, 7 and 10) under the label Nivea Men Life Hacks. Some of these ads have been aired on the internet, as well as on TV, as part of a campaign launched by the advertising company Stack for Nivea Men Originals in which "life hacks" are shared in order to help make grooming and life a little easier for Nivea Men customers. This category revolves around the following encompassing implicatures, which are indirectly conveyed in the ads mainly through the visual stimuli provided: men can find a way to overcome obstacles or difficulties (ad 1, mean=1.8, $\mathrm{SD}=0.5$; ad 5, mean=1,8, $\mathrm{SD}=0.6$; ad 7, mean=2.1, $\mathrm{SD}=0.3$; and ad 10, mean=2.0, $\mathrm{SD}=0.9$ ), men think originally (ad 1, mean=1.8, $\mathrm{SD}=0.4$; ad 5, mean $=2, \mathrm{SD}=0.5$; ads 7 and 10 , mean $=1.9, \mathrm{SD}=0.6$ ); and men who are resourceful, are more successful in their lives (ad 1 , mean $=2.2, \mathrm{SD}=0.8$; ad 7 , mean $=2.6, \mathrm{SD}=0.8$, and ad 10 , mean=2.2, $\mathrm{SD}=1.0$ ).

For instance, in ad 1 a young confident man (mean=1.8. SD=0.6) is getting ready for his soccer game while facing different situations in which he puts into practice different life hacks. One of the implied assumptions conveyed aims to debunk the myth that male skincare is time-consuming and cumbersome by establishing a parallelism between life hacks which take little time, and the use of Nivea for Men as yet another of these life hacks that helps making grooming easier and hassle-free (ad 1 mean=1.8, SD=0 .8). Thus, the male voice-over in ad 1 addresses the audience with a direct question: "Wanna make the most out of life?", to immediately provide the solution: "then hack it". Then, we are faced with different hacks that the man puts into practice as part of his Sunday routine: charging his phone using the telly's USB, stacking his clothes on their side to find them faster, putting his stinky trainers in the freezer, etc., which aid the inferential processing of the implicatures which portray men as inventive, resourceful and able to think originally. As the male voice-over urges the audience to use Nivea Men Originals to look and feel good, the audience faces a shot of the male character putting on the lotion with ease, as implying that Nivea is another of this fast savvy hacks.

The other three ads in the corpus portray male characters putting into practice savvy life hacks for daily situations such as fixing a punctured soccer ball with an egg, opening a bottle with a piece of paper, or keeping cake super fresh for several days. These ads are made up of a mini-drama and the only linguistic stimuli provided is the issue to be tackled, which is superimposed on the screen, i.e., "Keep cake super fresh for days" (ad 7), and a closing line from Nivea that reads: 'Nivea. It starts with you'. The faces of the male personae employed are not shown, as the focus is on their hands while they carry out the tricks, so fragmentation of body parts is pervasive here in an attempt to emphasize a high level of activity on the part of the represented participants. These visual choices 
are also indicative of a desire to index the product with manly features by endowing the represented participants with instrumentality. In other words, the use of body fragmentation and shots displaying the hands of the protagonists indexes their ability and passion for gadgets and/or technology, thus casting doubts on their preoccupation with appearance. The audience is invited to contemplate modern men who are impersonalized as their faces are not shown, while their bodies are conceptualized as "body-as-process" (Franzoi, 1995), that is, the body is seen as a functional machine whose instrumentality is of higher relevance than its beauty.

It is also worth mentioning that these ads feature guitar music while the problem is presented but this music abruptly changes to a more melodic kind of music when the key aspect of the trick is revealed, that is, when the male participant is solving the problem. This change signifies that men can also do things in a smooth and delicate way. For example, in the fix your ball with an egg, when the man gently pumps the ball to inflate it, the music turns to a softer melody, as if emphasizing its more delicate skills ${ }^{7}$. Once he finishes, the guitar music is used again and he is ready to kick the ball, hence emphasizing that the man is back for action. Further implied assumptions to be derived from these ads are that men are good at home hacks especially in the ads which deal with keeping a cake super fresh for days, and the one about opening a bottle without an opener ( ad 7, mean=1.9, $\mathrm{SD}=0.6$, and ad 10, mean=2.2, $\mathrm{SD}=1.0$ ).

\section{Concluding remarks}

Taking as a starting premise the fact that ads are complex semiotic practices and considering advertising's current reliance on linguistic and non-linguistic modes, a semiotic pragmatic analysis of a corpus of male toiletries TV ads has been carried out in this article. The main underlying aim was to unveil the male identities enacted in the ads through the analysis of the pragmatic notion of implicature together with attention to how male personae are portrayed from an interpersonal point of view within Kress and van Leeuwen's (1996, 2006) framework of visual semiotics. The critical agenda of this article lies in its desire to evaluate what media images of men are enacted in these contemporary ads, considering that media representations have been said to lie at the core of what a culture expects of its men (cf. Craig, 1992; Hanke, 1998). In order to the aid the rigour of my analysis, I empirically tested a set of implied assumptions obtained through the inferential processing of the ads as a first step, with a group of ten informants who evaluated a total of 164 assumption on a Likert scale (1-5) to express their degree of agreement. The percentage of overall agreement on the assumptions tested was quite high $74.3 \%$, and thus, in a second stage I bundled the assumptions into the following recurrent thematic categories or repertoires which present ad male personae who consume grooming products: (i) the gender divide, i.e., men do not groom like women; (ii) male's sexual power linked to product consumption; (iii) men's manpower as either achieved and/or reaffirmed through manly activities and toughness, and (iv) the savvy resourceful man.

Although male grooming has been a common and accepted practice among men since the 80s (Moore, 1989), advertisers are ready to have their cake and eat it too. In other words, while explicitly tackling the issue of male face care through shaving and body moisturizing products, there seems to be a need to still rely on stereotypical constructs which indirectly aim to endow male grooming with more masculine properties

\footnotetext{
${ }^{7}$ Although no implied assumptions were envisaged to be assessed for the use of auditory stimuli in this article, some of the informants pointed to the fact that the change of music in the 3 Nivea ads somehow meant that the man was at that point using 'softer' skills, as if emphasizing his having a more delicate side.
} 
in order to avoid the stigma it has had over the years as a typically female activity (Moore, 1989). In this respect, the ads which fall under the first thematic category help reify traditional hegemonic beliefs that view male and female as different in general, but especially in the arena of grooming in an attempt to reassure their potential buyers of their untouched masculinity (cf. Scheibling, 2014, for similar insights). As Rohlingher (2002:63) states:

\footnotetext{
Because masculinity requires both the avoidance and repudiation of all behaviours associated with femininity, a man must engage in an incessant surveillance of his performances to ensure that he is sufficiently masculine (Connell, 1995; Fracher and Kimmel, 1995; LeMoncheck, 1985).
}

Thus, the ads assessed stress several traits of female grooming practices, such as the fact that it is time-consuming and complicated, in an attempt to set up a diving line between male and female face care routines. For example, they convey, with varying degrees of explicitness, that male's face care is simple and hassle-free, a fact that makes men more practical. Even though women are absent from many of the ads within this thematic category, the audience is indirectly invited to recreate this comparison and thus activate their background knowledge about female grooming practices as something negative and not desirable for a man. Accordingly, celebrities, such as Real Madrid players are employed to reify the belief that real men can groom while still embracing the essence of what it takes to be a man. Not in vain, research carried out by Messner (1992) and Sargent (2001) has concluded that men tend to use more dominant masculine traits when engaged in non-typical masculine activities within a feminised environment.

The second thematic category encompasses those ads which emphasize sexual power as a male trait that the product helps to enhance and/or made more visible in a man. Sexuality, then, becomes the trademark of masculinity, or as Fracher and Kimmel (1995) have noted: "Gender informs sexuality; sexuality confirms gender". Ads in this group are characterised by the portrayal of pervasive female ad personae that act as a sexual reward for product consumption while serving the purpose of endorsing male consumption of such grooming products, and thus normalizing the consumption of these products, as they are desirable for women. The different male identities enacted display men engaged in traditional manly activities, such as lumbering, or in blue-collar jobs in which they manipulate tools, (both settings exclude women as they are manly activities that require strength and resilience) or winning contests, while also winning the girl. Other ads portray men who consume grooming products and are, thus, 'ahead of the game' with regard to their sexual abilities to seduce women. Women's poses in these ads conforms to Goffman's (1979) belief that they serve subservient roles to men as they tilt their heads, look seductively to the camera while caressing or kissing the male participants.

The third thematic core invokes men's right to reframe and reaffirm their manpower through product consumptions, while the male personae portrayed are involved in traditional manly activities, such as car driving, soccer or any other sports, or have the quality of mental and physical toughness, as a trait deeply entwined with traditional masculine behaviour (cf. Thompson and Pleck, 1986). Men in these ads reclaim their masculinity by highlighting certain masculine markers. Thus, the ads in this group urge men to look tough but not rough, thus reminding them of the importance of avoiding roughness while keeping their tough character. These ads equate shaving and face care routines with manly activities such as driving or playing soccer, once again touching upon the topic of athletics and physical strength, in order to counteract the fact that preparing for shaving, with its washing, balming, mirror gazing, etc., would irremediably position the masculine subject in a clearly feminine scenario. 
Finally, the fourth thematic category depicts a modern savvy man who tries to make the most out of life and who is resourceful, in a wide variety of social situations. The main implied assumptions points to men who are inventive and not eager to spend a long time grooming themselves, but rather value life hacks, with the implicature that Nivea for Men can be one of those tricks.

The exception is the L'Oréal ads which feature celebrities as product endorses and in which male and female participants tend to be portrayed together. Women in these ads act as mere adornments who feel irresistibly attracted to the male participants, while sometimes addressing the audience through demand gazes which invite the potential male consumer to participate in the scenario in which the ad personae are sexually engaged. In a similar vein, in the Clinique ones, for instance, men adopt a more aesthetic pose, as they display a low level of activity, while looking intently at the viewer, as if inviting them to share the experience depicted or as if indirectly seeking to obtain their complicity. Likewise, the use of body parts and naked bodies is also a common aspect to take into account. Traditionally, the male body has been viewed in terms of its instrumentality, although recently the focus has shifted towards the male body as decorative (Morrison et al., 2003) and thus, it is common to find men wearing no shirt, displaying their naked torso, revealing their pectorals and muscular bodies. This fragmentation, so typical of female characters (cf. Author 2018, under review), illustrates Franzoi's (1995) construct of the body-as object, in which body parts are shown, a fact that stresses the aesthetic attributes of the male body, which is on display to be looked at (cf. Kolbe and Albanese, 1996).

From these findings, it can be concluded that the ads under analysis are not highly representative of the different male identities at work in contemporary society, or in other words, the advertising of contemporary grooming products does not seem to keep pace with societal changes. Rather, some of the male identities touched upon by the ads are still illustrative of Connell's (1995) defining traits for hegemonic masculinity such as the qualities of being strong/tough together with the role of the sport man. Likewise, these ads portray male identities which conform to what Pollack (1989) has defined as the "boy code", that is, the fact that society teaches boys their roles by emphasizing qualities such as strength, valour, success, and avoidance of feminine traits.

On the other hand, advertisers' portrayals of men who consume grooming products constrain them within the realm of heterosexuality, thus targeting a well-defined group of men. With the exception of a couple of ads which make use of sexual innuendo but which lack the presence of a female character to somehow endorse the product consumption, most of the ads place men in heterosexual relationships. Therefore, heteronormativity is viewed as the only possible reading for the male population who consumes such products, with the exclusion of, for example, the gay population. Women, for their part, are commonly depicted as sexual rewards for the consumption of male products, and thus, their bodies objectified (cf. Kilbourne; 2000; Bordo, 1993). Likewise, even if other ads are less reliant on such conventional male constructs, they still present men who use grooming products as engaged in traditional manly activities, such as car driving, sports or by emphasizing their physical strength. In a word, men are told to consume grooming products but they are simultaneously shown how to do it or warned to avoid doing it the female way. The paradox is obvious since as Hall (2014:35) states:

Despite the difficulties surrounding the concept of hegemonic masculinity, it would seem that it is still relevant in helping us to understand how men manage their masculinities in the realm of traditional feminised activities such as image enhancement. 
Even if the effects that the portrayals of male identities may have on children and adolescents' gender role development was not the aim of this paper, it is true that it makes a valid motivation for its critical agenda. Following from this, the depiction of somehow unattainable identities, i.e., those which impose bodies with high muscularity (Pope et al., 2000; Olivaridia et al., 2004), may bring anxiety and insecurity to the lives of adult men while also conveying a somehow distorted view of what it takes to be a man through the consumption of male products. Thus, current advertising should strive towards a more egalitarian and truthful depiction of men considering that the media are a window and an important influence on children's socialization process to the point that the differences in how men and women or boys and girls behave is "a function of the typical roles that each is expected to play within society (Eagly et al. 2000). In other words, there should be a rising awareness of the potential costs that hegemonic portrayals may have not only for men but also for women.

Last, but not least, like all research, the findings obtained here cannot be deemed to be conclusive or exhaustive. Further avenues for research should contemplate the compilation of a bigger corpus, with the inclusion of other brands in order to widen the spectrum and obtain more conclusive evidence of the different male identities conveyed in contemporary advertising portrays.

\section{Acknowledgements}

\section{References}

Alexander SM (2003) Stylish hard bodies: Branded masculinity in Men’s Health Magazine. Sociological Perspectives 46: 535-554.

Atlas JD (2000) Logic, Meaning, and Conversation: Semantical Underdeterminacy, Implicature, and the Semantics/Pragmatics Interface. New York: Oxford University Press.

Attwood F (2005). "Tits and ass and porn and fighting”: Male heterosexuality in magazines for men. International Journal of Cultural Studies, 8(1), 83-100.

Author (2018, under review)

Author (2018, in press)

Author (2013)

Barthel D (1992) When men put on appearances: Advertising and the social construction of masculinity. In Craig S (ed.) Men, masculinity, and the media. Newbury Park, CA: Sage, pp. 137-153.

Barthel D (1988) Putting on appearances. Gender and advertising. Temple University Press: Philadelphia.

Belk, RW (2004) Men and their Machines. Advances in Consumer Research 31: 273-278.

Benwell, B (2003) Introduction: Masculinity and men's lifestyle magazines. In Benwell, Bethan (ed.) Masculinity and Men's Lifestyle Magazines 6-29. Oxford: Blackwell.

Bogetić K (2018) Normal straight gays: lexical collocations and ideologies of masculinity inpersonal ads of Serbian gay teenagers. In Milani T (Ed.), Queering Language, Gender and Sexuality. Equinox, pp. 225-255.

Bordo S (1993) Unbearable weight: Feminism, Western culture and the body. Berkeley: University of California Press.

Bordo S (1999) The Male Body: A New Look at Men in Public and in Private. Farrar, Straus and Giroux.

Brandth B (1995) Rural Masculinity in Transition: Gender images in tractor advertisements. Journal of Rural Studies, 11(2): 123-133.

Brandth B and Haugen MS (2000) From lumberjack to business manager: Masculinity in the Norwegian forestry press. Journal of Rural Studies 16 (4): 343-55.

Bynon J (2002) Masculinities and culture. Milton Keynes, UK: Open University Press.

Byrnes N (2006) Secrets of the male shopper. Business Week 3999: 44-54. 
Caldas-Coulthard C R, van Leeuwen K (2002) 'Stunning, Shimmering, Irridescent: Toys as the Representation of Gendered Social Actors'. In Litosseleti, L, Sunderland J, (2nd edN.) Gender Identity and Discourse Analysis. Amsterdam: John Benjamins, pp. 100-101.

Carrigan T, Connell R, Lee J (1985) Towards a new sociology of masculinity. Theory and Society, 14:551-604.

Connell RW (1987) Gender and Power: Society, the Person and Sexual Politics. Stanford, CA: Stanford University Press.

Connell RW (1995) Masculinities. Cambridge: Polity.

Craig S (1992) Considering Men and the Media. In Craig S (ed.) Men, Masculinity and the Media. New York: Sage Publications, pp. 1-7.

Daechun A (2007) Relating Hofstede's masculinity dimension to gender role portrayals in advertising A cross-cultural comparison of web advertisements. International Marketing Review, 24(2): 181-207.

De Gregorio-Godeo E (2009). British men’s magazines' scent advertising and the multimodal discursive construction of masculinity: a preliminary study. Estudios Ingleses de la Universidad Complutense 17: 9-36.

Dick A, Chakravarti, D and Biehal G (1990) Memory-based inferences during consumer choice. Journal of Consumer Research 17(1): 82-93.

Eagly AH, Wood W, Diekman AH. (2000) Social role theory of sex differences and similarities: A current appraisal. In Eckes T, Trautner HM, (eds) The developmental social psychology of gender. Mahwah, NJ: Erlbaum, pp. 123-174.

Feasy R (2009) Spray more, get more: masculinity, television advertising and the Lynx effect. Journal of Gender Studies 18(4): 357-368.

Featherstone M (1991) The body in consumer culture. In Featherstone M, Hepworth, M and Turner BS (eds) The Body: Social Process and Cultural Theory. London: Sage, pp. 170196.

Firat F and Venkatesh A (1993) Postmodernity: the age of marketing. International Journal of Research in Marketing, 10(3): 227-249.

Follo G (2002) A hero's journey: Young women among males in forestry education. Journal of Rural Studies 18:293-306.

Fowles J (1996) Advertising and popular culture. Sage Publications: Thousand Oaks.

Fracher J and Kimmel M (1995) Hard issues and soft spots: Counselling men about sexuality. In Kimmel M, and Messner M (eds) Men's lives (3rd ed.). Boston: Allyn and Bacon, pp. 365-374.

Franzoi S L (1995) The body-as-object versus the body-as-process: Gender differences and gender considerations. Sex Roles 33: 417-437.

Gazdar G (1979) Pragmatics: Implicature, Presupposition and Logical Form. New York: Academic Press.

Geis ML (1982) The Language of Television Advertising. New York: Academic Press.

Giddens A (1991) Modernity and Self-Identity: Self and Society in the Late Modern Age. Standford CA: Standford University Press.

Gill R (2003) Power and the production of subjects: a genealogy of the New Man and the New Lad. In B. Benwell (eds.), Masculinity and Men's Lifestyle Magazines. Malden, MA: Blacwell Publishing, Ltd.

Gill R, Henwood K, and McLean C (2005) Body projects and the regulation of normative masculinity. Body and Society 11 (1): 37-62.

Goffman E (1979) Gender Advertisements. New York: Harper and Bow.

Grice HP (1989) Studies in the Way of Words. Cambridge, Mass: Harvard University Press.

Grisot C (2017) A quantitative approach to conceptual, procedural and pragmatic meaning: Evidence from inter-annotator agreement. Journal of Pragmatics 117: 245-263.

Hakala U (2003) Quantitative and qualitative methods of analysing advertising: content analysis and semiotics. Publications of the Turku School of Economics and Business Administration, Series Discussion and working papers 5: 2003. Turku.

Hakala U (2006) Adam in ads: A thirty-year look at mediated masculinities in advertising in Finland and the US. Turku: Turku School of Economics. 
Hall ET (1966) The Hidden Dimension. New York, NY, US: Doubleday \& Co.

Hall M, Gough B, Seymour-Smith S, Hansen S (2018) Online constructions of metrosexuality and masculinities: a membership categorisation analysis, in Milani T (ed), Queering Language, Gender and Sexuality. Equinox, pp 179-198).

Hall M (2014) It's a Metrosexual Thing: A discourse analytical examination of masculinities. PhD Dissertation. Nottingham University.

Hall M, Gough B and Seymour-Smith S (2012). “I'm METRO, NOT Gay!”: A discursive anlaysis of men's accounts of makeup use on Youtube”. The Journal of Men’s Studies, 20(3): 209226.

Halliwell E, Dittmar H (2003) A qualitative investigation of women's and men's body image concerns and their attitudes toward ageing. Sex Roles 49 (11-12):675-684.

Hanke R (1998) Theorizing Masculinity With/In the Media. Communication Theory 8(2): 183203.

Harrison C (2008) Real men do wear mascara: Advertising discourse and masculine identity. Critical Discourse Studies 5(1), 55-73.

Jackson P (1994) Black male: Advertising and the cultural politics of masculinity. Gender, Place \& Culture, 1(1): 49-59.

Kacen JK (2000) Girrrl power and boyyy nature: the past, present, and paradisal future of consumer gender identity. Marketing Intelligence and Planning 18 (6/7): 345-355.

Katz J (2003) Advertising and the Construction of Violent White Masculinity: From Eminem to Clinique for Men. In Dines G and Humez J (eds) Gender, Race and Class in Media: A Text Reader. (Second edition). Thousand Oaks, CA: Sage Publications, pp 349-358.

Kervin D (1990). Advertising masculinity: the representation of males in Esquire advertisements. Journal of Communication Inquiry, 14, 51-70.

Kilbourne J (2000) Can't Buy My Love: How advertising changes the way we think and feel. New York, NY: Touchstone.

Kimmel M S (1996) Manhood in America: A Cultural History. New York: Free Press.

Kimmel MS (2004) Masculinity as homophobia: fear, shame, and silence in the construction of gender identity. In Murphy P (ed.) Feminism and masculinities Oxford: Oxford University Press, pp. 182-199.

Kimmel MS (2012) Manhood in America: A Cultural History. (3rd ed.). New York, NY: Oxford University Press.

Kolbe RH and Albanese PJ (1996) Man to Man: A Content Analysis of Sole-Male Images in Male-Audience Magazines. Journal of Advertising 25(4):1-20.

Kosetzi K and Polyzou A (2009) 'The perfect man, the proper man' Construals of masculinities in Nitro, a Greek men's lifestyle magazine-an exploratory study. Gender and Language 3(2): 143-180.

Kress G and van Leeuwen T (1996) Reading Images: The Grammar of Visual Design. London: Routledge.

Kress G and van Leeuwen T (2006) Reading Images: The Grammar of Visual Design. ${ }^{\text {nd }}$ edition. London: Routledge.

Lee DH and Olshavsky RW (1995) Conditions and consequences of spontaneous inference generation: A concurrent protocol approach. Organizational Behaviour and Human Decision Processes 61(2):177-189.

LeMoncheck L (1985) Dehumanizing women: Treating persons as sex objects. Totowa, NJ: Rowman and Allanheld.

Levinson SC (2000) Presumptive Meanings. The Theory of Generalized Conversational Implicature. Cambridge, MA: MIT Press.

L’Oréal (2010) UK Mens' Grooming Report 2010. Retrieved January 18, 2012, from www.loreal.co .uk/_en/_gb/pdf/LOreal_Mens_Grooming_Report_FINAL.pdf.

Luyt R (2012) Constructing hegemonic masculinities in South Africa: the discourse and rhetoric of heteronormativity. Gender and Language 6(1): 47-77.

Machin D (2007) Introduction to Multimodal Analysis. London. Arnold.

Machin D, Mayr A (2012) How to do Critical Discourse Analysis: A multimodal introduction. Sage Publications Ltd. 
MacKinnon K (2003) Representing men: maleness and masculinity in the media. London: Arnold. McNeill LS and Douglas K (2011) Retailing masculinity: Gender expectations and social image of male grooming products. Journal of Retailing and Consumer Services 18: 448-454.

McNeill LS and Firman JL (2014) Ideal body image: A male perspective on self. Australasian Marketing Journal 22: 136-143.

Messner MA (1992) Power at play: Sports and the problem of masculinity. Boston, MA: Beacon Press.

Meuser M (2001) “Ganze Kerle”, “Anti-Helden” und andere Typen. Zum Männlichkeitsdiskurs in neuen Männerzeitschriften. In Döge P and Meuser M (eds.) Männlichkeit und soziale Ordnung: Neuere Beiträge zur Geschlechterforschung. Opladen, Germany: Leske and Budrich, pp. 219-36.

Mintel Oxygen (2012) Men's Toiletries-UK. Retrieved January 9, 2013, from http://oxygen.mintel.com/display/590373/?highlight=true.

Moeschler J (2012) Conversational and conventional implicatures. In Schmid HJ (ed.) Cognitive Pragmatics. Boston and Berlin: De Gruyter Mouton, pp. 405-433

Moore S (1989) Getting a bit of the other - the pimps of postmodernism. In Chapman R and Rutherford J (eds) Male Order: Unwrapping Masculinity. London: Lawrence and Wishart, pp. 165-192.

Morgan DHJ (1992) Discovering men. London: Routledge.

Morrison TG, Morrison MA, Hopkins C (2003) Striving for bodily perfection? An exploration of the drive for muscularity in Canadian men. Psychology of Men and Masculinity 4: 111120.

Morse M (1983) Sport on television: replay and display. In Kaplan E (ed.) Regarding Television: critical approaches-an anthology. Frederick, MD: The American Film Institute, pp. 4466.

Mort F (1996) Cultures of Consumption: Masculinities and Social Space in Late twentiethCentury Britain. London: Routledge.

Nixon S (1996) Hard Looks: Masculinities, Spectatorship and Contemporary Consumption. London: UCL Press.

Nixon S (2000) Exhibiting masculinity. In Hall S (ed.) Representation. Cultural representations and signifying practices. Sage Publications: London, pp. 291-336.

Olivaridia R, Pope HG, Borowiecki JJ and Cohane GH (2004) Biceps and body image: The relationship between muscularity and self-esteem, depression, and eating disorder symptoms. Psychology of Men and Masculinity 5: 112-120.

Ostberg J (2009) Conservative rebels: identity struggles by resurrecting an imagined past. Paper presented at the meeting of Consumer Culture Theory Conference, Ann Arbor, MI.

Patterson M, Elliott R (2002) Negotiating masculinities: Advertising and the inversion of the male gaze. Consumption, Markets and Culture 5(3): 231-246.

Plakoyiannaki E, Zotos Y (2009). Female role stereotypes in print advertising: Identifying associations with magazine and product categories. European Journal of Marketing, 43: 1411-1434.

Pollack W (1989) Real Boys: Rescuing Our Sons from the Myths of Boyhood. New York: Henry Holt and Company.

Pope HG, Gruber AJ, Mangweth B (2000) Body image perception among men in three countries. Journal of American Psychiatry 157: 1297-1301.

Renkema J (2004) Introduction to Discourse Studies. Amsterdam: John Benjamins Publishing Company.

Ridder K (2005) Male grooming. Today's enlightened men know there's no shame in looking good. The Modesto Bee, April 1, 2005. Section G, 1-2.

Ringrow H (2016) The Language of Cosmetics Advertising. Palgrave: McMillan.

Rohlinger DA (2002) Eroticizing Men: Cultural Influences on Advertising and Male Objectification. Sex Roles 46 (3/4): 61-74.

Ross F (2012) Contemporary men's fashion and new technology: shifting perceptions of masculinity, menswear aesthetics and consumption. Fashion Colloquia, London College of Fashion September 2011. 
Salzman M, Matathia I, O’Reilly A (2005) The Future of Men. Palgrave.

Sargent P (2001) Real Men or Real Teachers: Contradictions in the Lives of Men Elementary School Teachers. Harriman, TN: Men's Studies Press.

Scheibling C (2014) It's a Metrosexual Thing: A Discourse Analytical Examination of Masculinities. PhD thesis.

Schroeder JE and Zwick D (2004) Mirrors of Masculinity: representation and identity in advertising images. Consumption, Markets and Culture 7(1):21-52.

Simpson M (1994). Here come the mirror men. The Independent. Retrieved January 4, 2008, from http://www.marksimpson.com/pages/journalism/mirror_men.html.

Simpson M (2002) Meet the Metrosexual. Salon. Retrieved January 4, 2008, from http://dir.salon.com/story/ent/feature/2002/07/22/metrosexual/index2.html.

Sperber D and Wilson D (1995) Relevance Theory: Communication and Cognition ( ${ }^{\text {nd }}$ ed). Oxford: Blackwell.

Sperber D and Wilson D (1986) Relevance Theory: Communication and Cognition. Oxford: Blackwell.

Tashakkori A, and Creswell J (2007) The new era of mixed methods. Journal of Mixed Methods Research 1:3-7.

Thompson CJ and Hirschman EC (1995) Understanding the socialized body: A poststructuralist analysis of consumers' self-conceptions, body images, and self-care practices. Journal of Consumer Research 22(2):139-153.

Thompson E H and Pleck JH (1986) The Structure of Male Role Norms. American Behavioral Scientist 29:531-43.

Van Dijk TA (2001) Discourse, ideology and context. Folia Lingüística XXXV(1-2): 11-40.

Van Dijk TA (2005) War rhetoric of a little ally: Political implicatures and Aznar's legitimatization of the war in Iraq. Journal of Language and Politics 4 (1): 65-91.

Van Dijk TA (2006) Politics, ideology, and discourse. In Brown K (ed.) The Encyclopedia of Language and Linguistics, vol. 9. Oxford; New York: Pergamon Press, pp. 728-740.

Wernick A (1991) Promotional culture: advertising, ideology and symbolic expressions. London: Sage.

Wheaton B (2003) Lifestyle sport magazines and the discourses of sporting masculinity. The Sociological Review 51(1): 193-221.

Wicks D and Mills AJ (2000) Deconstructing Harry: a critical review of men, masculinity and organization. The Finnish Journal of Business Economics 49(3): 327-349.

Williamson J (1978) Decoding Advertisements. London: Marion Boyars.

Wodak R (2007) Pragmatics and Critical Discourse Analysis. A cross-disciplinary Analysis. Pragmatics and Cognition 15 (1): 203-225. 


\begin{tabular}{|c|c|}
\hline \multicolumn{2}{|r|}{ NIVEA ADS } \\
\hline $\begin{array}{c}\text { Ad 1. Nivea Men } \\
\text { Originals: Life } \\
\text { Hacks }\end{array}$ & $\begin{array}{l}\text { The ad implies that men can find a way to overcome difficulties and obstacles } \\
\text { The ad implies that men think originally } \\
\text { The ad implies that using Nivea Men Originals is another of these tricks to make grooming hassle } \\
\text { free } \\
\text { The man in the ad looks confident }\end{array}$ \\
\hline $\begin{array}{l}\text { Ad 2. Nivea Men } \\
\text { Crème: } \\
\text { Lumberjack } \\
\text { Competition }\end{array}$ & $\begin{array}{l}\text { The men in the ad are strong and determined } \\
\text { The men in the ad look tough } \\
\text { The ad implies that men like to compete with other men } \\
\text { The ad implies that if you use the product you will be prepared to face risk and difficulties } \\
\text { The ad implies that men who use Nivea win in a difficult situation } \\
\text { The men in the ad are involved in traditional masculine activities } \\
\text { The ad visually implies that men who use Nivea attract women }\end{array}$ \\
\hline $\begin{array}{l}\text { Ad 4. Nivea Men } \\
\text { Originals: Forget } \\
\text { complicated. }\end{array}$ & $\begin{array}{l}\text { The ad implies that men and women groom in a different way } \\
\text { The ad implies that women's face care is complicated and time-consuming } \\
\text { The ad visually implies that there is something unnatural in men wanting to look after their skin } \\
\text { the woman's way } \\
\text { The ad implies that men value simple and fast skin care } \\
\text { The ad implies that men are more practical when it comes to face care than women } \\
\text { The ad visually implies that the man feels better after using the Nivea Men moisturizer } \\
\text { The ad visually implies that women will notice men after they use the moisturizer } \\
\text { The man in the ad is determined } \\
\text { The ad visually implied that women feel attracted to men who use grooming products }\end{array}$ \\
\hline $\begin{array}{l}\text { Ad 6. Nivea Body } \\
\text { Lotion for Men. }\end{array}$ & $\begin{array}{l}\text { The ad implies that men do not normally use body lotions } \\
\text { The ad visually implies that the man who applies the body lotion gets the sexy girl waiting for him } \\
\text { The ad visually implies that women value men who moisturized their skin } \\
\text { The ad visually implies that Nivea can help a man seduce a woman }\end{array}$ \\
\hline $\begin{array}{l}\text { Ad 7. Nivea } \\
\text { Original Life Hack: } \\
\text { Keep cake super } \\
\text { fresh for days }\end{array}$ & $\begin{array}{l}\text { The ad implies that men can find a way to overcome difficulties and obstacles } \\
\text { The ad implies that men think originally } \\
\text { The ad implies that men like the ones in the ad also use Nivea Original products } \\
\text { The ad implies that men are good at home hacks } \\
\text { The ad implies that a man who is resourceful is more successful }\end{array}$ \\
\hline $\begin{array}{l}\text { Ad 8. Nivea for } \\
\text { Men: Shaving }\end{array}$ & $\begin{array}{l}\text { The ad implies that men are tough enough to shave with different blades } \\
\text { The ad implies that Nivea gel for shaving can make shaving less painful } \\
\text { The ad visually implies that the men in the ad are strong and have resilience } \\
\text { The ad implies that any change starts with you as the protagonist }\end{array}$ \\
\hline $\begin{array}{l}\text { Ad 9. Nivea for } \\
\text { Men: Road to } \\
\text { recovery }\end{array}$ & $\begin{array}{l}\text { The ad implies that men and women groom in a different way } \\
\text { The ad implies that women's face care is complicated and time-consuming } \\
\text { The ad implies that men value simple and fast skin care } \\
\text { The ad visually implies that the man feels better after using the Nivea Men moisturizer } \\
\text { The ad visually implies that men are more intelligent than women for using Nivea Men } \\
\text { The man in the ad looks confident } \\
\text { The man in the ad looks happy after using the product } \\
\text { The ad implies that women are not so evolved in their use of skin care products }\end{array}$ \\
\hline
\end{tabular}




\begin{tabular}{|c|c|}
\hline $\begin{array}{c}\text { Ad } 11 . \text { Men! This is } \\
\text { your Créme }\end{array}$ & $\begin{array}{l}\text { The ad implies that real men are tough } \\
\text { The ad implies that real men face adversities with a stoic attitude } \\
\text { The ad implies that real men take care of their skin } \\
\text { The ad implies that men and women groom in a different way } \\
\text { The men in the ad are happy with the crème } \\
\text { The men in the ad are concerned about their skin } \\
\text { The ad implies that Nivea can help men take care of their skin but not like women do }\end{array}$ \\
\hline $\begin{array}{l}\text { Ad 12. Nivea Ice } \\
\text { Mud Serum: Would } \\
\text { you fix it like a } \\
\text { lady? }\end{array}$ & $\begin{array}{l}\text { The ad implies that men and women groom in a different way } \\
\text { The ad implies that natural ingredients like mud help clean your skin } \\
\text { The ad implies that men should not take care of their skin the woman's way } \\
\text { The ad implies that the Nivea Ice Mud Serum is easy to use } \\
\text { The man in the ad looks confident } \\
\text { The man in the ad is happy with the serum } \\
\text { The man in the ad is concerned about his skin }\end{array}$ \\
\hline \multirow[t]{2}{*}{$\begin{array}{l}\text { Ad 13. Nivea Men } \\
\text { Crème: the Double }\end{array}$} & $\begin{array}{l}\text { The ad implies that the male character that uses the product is more successful because he is using } \\
\text { Nivea Men Crème } \\
\text { The ad implies that the male character that uses the product is a better entertainer because he is } \\
\text { using Nivea Men Crème } \\
\text { The ad implies that the male character that uses the product is better at soccer because he is using } \\
\text { Nivea Men Crème } \\
\text { The ad implies that the male character that uses the product attracts people's attention more easily } \\
\text { because he is using Nivea Men Crème } \\
\text { The ad implies that the male character that uses the product can be better endowed because he is } \\
\text { using Nivea Men Crème } \\
\text { The ad implies that any change in life starts with you } \\
\text { The ad implies that using the product can bring about huge changes in your life and relationships } \\
\text { with others }\end{array}$ \\
\hline & L'ORÉAL ADS \\
\hline $\begin{array}{l}\text { Ad 14. Get Your } \\
\text { Game Face On } \\
\text { with L'Oréal Men } \\
\text { Expert. }\end{array}$ & $\begin{array}{l}\text { The ad implies that men are not afraid of difficult situations } \\
\text { The ad implies that men excel because they work hard and are creatures of habit } \\
\text { The men in the ad are involved in an activity } \\
\text { The men depicted in the ad are tough and strong } \\
\text { The ad implies that men need to be ready to fight and to face the unexpected in any situation } \\
\text { The ad implies that men have a warrior inside } \\
\text { The ad implies that men like sports } \\
\text { The ad implies that men should take care of their shaving as it is part of how they play in life }\end{array}$ \\
\hline $\begin{array}{l}\text { Ad 15. Hydra } \\
\text { Energetic Skin } \\
\text { starring Lewis } \\
\text { Hamilton L'Oréal } \\
\text { Men Expert }\end{array}$ & $\begin{array}{l}\text { The ad implies that L'Oréal products are not deceptive } \\
\text { The ad implies that men's faces can also show signs of fatigue or tiredness } \\
\text { The ad implies that using the product can make you look and feel refreshed } \\
\text { The ad implies that face care routine with L’Oréal is easy and hassle-free } \\
\text { The ad implies that the product is made by experts } \\
\text { The ad implies that men are as strong as lions } \\
\text { The man in the ad addresses the audience seductively } \\
\text { The women in the ad are visually attracted to the man who uses the product }\end{array}$ \\
\hline \begin{tabular}{c|} 
Ad 16. L'Oréal \\
Men Expert Hydra \\
Energetic Skin \& \\
Stubble \\
Decembeard
\end{tabular} & $\begin{array}{l}\text { The ad implies that using the product can make your beard and stubble look sexy } \\
\text { The ad implies that the routine to get a sexy beard is simple and easy } \\
\text { The ad implies that women feel sexually attracted to men who look after their beards } \\
\text { The ad visually emphasizes highly eroticized female body parts } \\
\text { The ad visually emphasizes highly eroticized male body parts } \\
\text { The man in the ad looks at the audience seductively } \\
\text { The woman in the ad looks at the audience seductively } \\
\text { The ad implies that using the product can help you attract women }\end{array}$ \\
\hline $\begin{array}{l}\text { Ad 17. L’Oréal } \\
\text { Men Expert Pure } \\
\text { Power Charcoal } \\
\text { Wash }\end{array}$ & $\begin{array}{l}\text { The ad implies that having an imperfect skin can affect your manpower } \\
\text { The man in the ad is ready to fight his problem } \\
\text { The man in the ad is happy after trying the product } \\
\text { The man in the ad looks at the audience seductively }\end{array}$ \\
\hline $\begin{array}{c}\text { Ad 18. Lewis } \\
\text { Hamilton - L'Oréal } \\
\text { Men Expert Hydra } \\
\text { Energetic }\end{array}$ & $\begin{array}{l}\text { The ad implies that living your life to the full can show negatively in your skin } \\
\text { The ad implies that the man in the ad is worried about his skin } \\
\text { The ad implies that the product will help you look less tired } \\
\text { The ad implies that face care routine with L'Oréal is easy and hassle-free } \\
\text { The ad implies that the product will help you seduce women } \\
\text { The man in the ad is confident }\end{array}$ \\
\hline $\begin{array}{l}\text { Ad. } 19 . \text { New } \\
\text { L'Oreal Vitalift } 5 \\
\text { feat. Hugh Laurie }\end{array}$ & $\begin{array}{l}\text { The character in the ad implies that ageing for men is not traumatic } \\
\text { The character in the ad implies that men learn lots of skills as they age } \\
\text { The character in the ad implies that men become more confident as they age }\end{array}$ \\
\hline
\end{tabular}




\begin{tabular}{|c|c|}
\hline & $\begin{array}{l}\text { The character in the ad implies that men can be more sexually appealing to women as they age } \\
\text { The character in the ad implies that ageing is not a downer for men } \\
\text { The man in the ad is happy with his age } \\
\text { The ad implies that Vitalift } 5 \text { is for men who are not worried about their skin but want to be } \\
\text { themselves }\end{array}$ \\
\hline $\begin{array}{c}\text { Ad 20. Hugh } \\
\text { Laurie - L'Oréal } \\
\text { Paris - Men Expert } \\
\text { Vita Lift }\end{array}$ & $\begin{array}{l}\text { The ad implies that when men reach their } 40 \text { s they do not do crazy things to fight the passing of } \\
\text { time } \\
\text { The ad implies that men should keep a positive attitude when ageing } \\
\text { The ad visually implies that men in their } 40 \text { s can still attract younger women } \\
\text { The ad visually implies that men in their } 40 \text { s are young and should enjoy life to the full } \\
\text { The ad implies that using Men Expert Vita Lift you can feel young and be yourself }\end{array}$ \\
\hline \multirow[t]{2}{*}{$\begin{array}{l}\text { Ad 21. Get Tough } \\
\text { with Hydra } \\
\text { Sensitive Skin } \\
\text { Range starring } \\
\text { Marlon Teixera } \\
\text { L'Oréal Men } \\
\quad \text { Expert }\end{array}$} & $\begin{array}{l}\text { The ad implies that men can suffer from discomfort and tight skin in their face } \\
\text { The ad encourages men to be tough } \\
\text { The ad implies that Hydra Sensitive Skin uses natural ingredients to treat your skin } \\
\text { The ad implies that L'Oréal is an honest brand that does not want to trick men } \\
\text { The ad visually implies that women love to caress a skin that's been well-taken care of. } \\
\text { The man in the ad looks seductively at the audience } \\
\text { The man in the ad looks satisfied after using the product } \\
\text { The ad focuses on highly eroticized male body parts } \\
\text { The man in the ad is confident about his looks }\end{array}$ \\
\hline & CLINIQUE ADS \\
\hline $\begin{array}{c}\text { Ad 22. Clinique } \\
\text { For Men Anti-Age } \\
\text { Skincare }\end{array}$ & $\begin{array}{l}\text { The ad implies that intellectual knowledge is more important than looks } \\
\text { The ad states that wanting to learn new things is the key to staying young } \\
\text { The ad implies that Clinique combines common sense and technology } \\
\text { The ad visually implies that modern men look after themselves } \\
\text { The ad employs close-ups of faces to convey intimacy } \\
\text { The ad implies that the science for looking good is easy and simple } \\
\text { The men in the ad are confident about their looks } \\
\text { The men in the ad look seductively at the audience }\end{array}$ \\
\hline $\begin{array}{l}\text { Ad 23. Clinique } \\
\text { For Men Normal- } \\
\text { Dry Skincare }\end{array}$ & $\begin{array}{l}\text { The ad implies that with Clinique looking after your skin is easy and simple } \\
\text { The ad implies that men who use Clinique are knowledgeable about football } \\
\text { The men in the ads look at the audience seductively } \\
\text { The ad implies that if you follow their advice you will be sexually successful with a partner ("Be } \\
\text { ready to score") } \\
\text { The ad visually implies that modern men look after themselves } \\
\text { The men in the ad are confident about their looks }\end{array}$ \\
\hline $\begin{array}{l}\text { Ad 24. Clinique } \\
\text { For Men Oil } \\
\text { Control Skincare }\end{array}$ & $\begin{array}{l}\text { The ad implies that having a shiny face is a drawback for a sexual partner to set eyes on you } \\
\text { The ad jokingly implies that if you get the shine out of your face, potential sexual partners will } \\
\text { focus on your other impressive features } \\
\text { The ad implies that the science behind looking good is easy and simple } \\
\text { The ad employs close-ups to convey intimacy } \\
\text { The Black man in the ad looks at the audience seductively } \\
\text { The men in the ad are confident about their looks } \\
\text { The ad visually implies that modern men look after themselves }\end{array}$ \\
\hline $\begin{array}{l}\text { Ad 25. Clinique } \\
\text { For Men The } \\
\text { Perfect Shave }\end{array}$ & $\begin{array}{l}\text { The ad implies that shaving is like driving } \\
\text { The ad implies that men like to drive } \\
\text { The ad implies that shaving can be simple and hassle-free } \\
\text { The ad implies that the science behind looking good is easy and simple } \\
\text { The men in the ad are confident about their looks } \\
\text { The ad visually implies that modern men look after themselves } \\
\text { The man in the ad looks at the audience seductively }\end{array}$ \\
\hline $\begin{array}{c}\text { Ad 26. Clinique } \\
\text { For Men There's a } \\
\text { science to looking } \\
\text { good }\end{array}$ & $\begin{array}{l}\text { The ad implies that the product is for men who already take care of themselves } \\
\text { The ad implies that men who use the product value design and cars } \\
\text { The ad implies that men who use the product like to have control over their lives } \\
\text { The ad implies that the science behind looking good is easy and simple } \\
\text { The men in the ad are confident about their looks } \\
\text { The ad visually implies that modern men look after themselves } \\
\text { The men in the ad looks at the audience seductively }\end{array}$ \\
\hline
\end{tabular}

